\title{
Case Studies of the Legal and Institutional Obstacles and Incentives to the \\ Development of Small-Scale Hydroelectric Power
}

\section{Executive Summary}

November 1979

Prepared for:

U.S. Department of Energy

Assistant Secretary for Resource Applications

Division of Hydroelectric Resources Development

Under Contract Numbers FG03-78RA23220 and AS02-78RA04934 


\section{DISCLAIMER}

This report was prepared as an account of work sponsored by an agency of the United States Government. Neither the United States Government nor any agency Thereof, nor any of their employees, makes any warranty, express or implied, or assumes any legal liability or responsibility for the accuracy, completeness, or usefulness of any information, apparatus, product, or process disclosed, or represents that its use would not infringe privately owned rights. Reference herein to any specific commercial product, process, or service by trade name, trademark, manufacturer, or otherwise does not necessarily constitute or imply its endorsement, recommendation, or favoring by the United States Government or any agency thereof. The views and opinions of authors expressed herein do not necessarily state or reflect those of the United States Government or any agency thereof. 


\section{DISCLAIMER}

Portions of this document may be illegible in electronic image products. Images are produced from the best available original document. 


\section{NOTICE}

This report was prepared as an account of work sponsored by the United States Government. Neither the United States nor the United States Department of Energy, nor any of their employees, makes any warranty, express or implied, or assumes any legal liability or responsibility for the accuracy, completeness, or usefulness of any information, apparatus, product, or process disclosed, or represents that its use would not infringe privately owner rights Reference herein to any specific commercial product, process, or service by trade name, mark, manufacturer, or otherwise, does not necessarily constitute or imply its endorsement, recommendation, or favoring by the United States Government or any agency thereof. The views and opinions of authors expressed herein do not necessarily state or reflect those of the United States Government or any agency thereof.

Ava1lable from:

National Technical Information Service

U.S. Department of Commerce

5285 Port Royal Road

Springfield, Virginia 22161

Price:

Printed Copy:

$\$ 8.00$
$\$ 4.00$

Microfiche: 
DOE/RA/23220-01

Dist. Category UC-97e

\section{Case Studies of the Legal and Institutional Obstacles and Incentives to the Development of Small-Scale Hydroelectric Power}

\section{Executive Summary}

November 1979

Prepared by:

9510765

Larry Schwartz, Principal Investigator

University of Washington

National Conference of State Legislatures _ $950 \quad 3477$

Denver, Colorado 80202

Under. Contract No. FG03-78RA23220

and

William Wilson, Principal Investigator-

Franklin Pierce Law Center

Concord, New Hampshire 03301

9511649

Under Contract No. AS02-78RA04934

Prepared for:

U.S. Department of Energy

Assistant Secretary for Resource Applications

Division of Hydroelectric Resources Development

Washington, DC 20461 


\section{FOREWORD}

The National Conference of State Legislatures' Small-Scale Hydroelectric Policy Project is designed to assist selected state legislatures in looking at the benefits that a state can derive from the development of small-scale hydro, and in carrying out a review of state laws and regulations that affect the development of the state's small-scale hydro resources. The successful completion of the project should help establish state statutes and regulations that are consistent with the efficient development of small-scale hydro.

As part of the project's work with state legislatures, seven case studies of smallscalc hydro sites were cumbucled to provide a general analysis and overview of the significant problems and opportunities for the development of this energy resource. The case study approach was selected to expose the actual difficulties and advantages involved in developing a specific site. Such an examination of real development efforts will clearly reveal the important aspects about small-scale hydro development which could be improved by statutory or regulatory revision. Moreover, the case study format enables the formulation of generalized opportunities for promoting small-scale hydro based on specific development experiences.

The case studies were conducted for NCSL by the Energy Law Institute of the Franklin Pierce Law Center and the Program in Social Management of Technology of the University of Washington. The subcontractors were selected from a group of responses to NCSL's request for proposal solicitation. The subcontractors and NCSL jointly selected the seven case study sites which reflect a variety of developers and site development scenarios. Upon selection of the sites, the subcontractors conducted comprehensive studies of each site which were developed into individual case study reports. The full case study reports, that are the basis for this Executive Summary, can be obtained from the National Technical Information Service.

While the approach of the case studies seems an effective way of developing information useful to state legislators and staff, the following qualifications should be 
noted. While reasonably accurate generalizations about the environment for hydroelectric development can be drawn from the seven case studies examined, the seven studies provide a limited sample and cannot exhaustively reveal all the potentially significant issues involved in hydroelectric development. In addition, a case study is not a perfect substitute for the actual experiences of a particular developer. Nevertheless, it would seem that the conclusions derived from the studies should be useful in identifying and illustrating possible remedies for at least some of the more significant problems confronting hydroelectric developers. At a minimurn, the information here should crystalize some legislative hydro policy options and suggest areas in need of additional inquiry.

The National Conference of State Legislatures' Small-Scale Hydroelectric Policy Project would like to express its appreciation to the following individuals in the preparation of this document.

Larry Schwartz

John G. Douglass

Jeffrey James

Larry A. Meyer

Professor Peter W. Brown

William $\mathrm{H}$. Wilson

Duillie R. Pupe

Frederick J. Schmidt

JoAnn Samson Shaw

Robert A. Olson

Gary Molnar

Additionally, NCSL and the subcontractors wish to thank the developers of the projects studied, the regulators and government officials in those states, and.numerous other persons without whose cooperation this report would not have been possible. 


\section{TABLE OF CONTENTS}

Energy Law Institute

Franklin Pierce Law Center

I. INTRODUCTION ..................... 1

II. A SUMMARY OF MAJOR CONCLUSIONS AND RECOMMENDATIONS • • • 4

A. Major Obstacles . . . . . . . . . . . . . . . . . 5

B. Major Incentives .. . . . . . . . . . . . . . . 6

III. THE CASES ........................... . 7

A. High Falls, Georgia . . . . . . . . . . . . . . . . . . 7

B. Boardman River, Michigan . . . . . . . . . . . . 8

C. Swanville Lake, Maine . . . . . . . . . . . . . . . . 10

D. Maxwell Locks, Pennsylvania . . . . . . . . . . . . 12

E. Cornell, Wisconsin . . . . . . . . . . . . . . . . . 13

IV. MAJOR OBSTACLES AND INCENTIVES TO HYDROELECTRIC

DEVELOPMENT AND RECOMMENDED ACTION . . . . . . . . . . 15

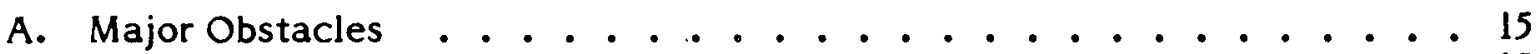

1. Delays, Contradiction and Redundancy in Licensing Process . . . . 15

2. Informational Deficiencies . . . . . . . . . . . . . . . . 17

3. Absence of State Hydroelectric Development Policies . . . . . . 18

4. Fish Passageways . . . . . . . . . . . . . . . . . . . . . 19

5. FERC User Fees and U.S. Army Corps of Engineers Water Storage Fees 2I

6. Intervention ...................... . 21

B. Major Incentives . . . . . . . . . . . . . . . . . . 22

1. Environmental Mediation . . . . . . . . . . . . . . 22

2. Feasibility and Licensing Grants and Loans . . . . . . . . . 23

3. Financing and Tax Incentives . . . . . . . . . . . . 23

4. Public Utility Regulatory Polcies Act of 1978 (PURPA) . . . . . . . 24

5. Short Form License Applications for Existing Dams . . . . . . . . 26

V. MINOR OBSTACLES AND INCENTIVES TO HYDROELECTRIC DEVELOPMENT

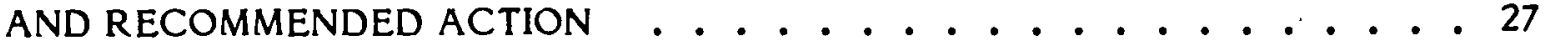

A. Minor Obstacles . . . . . . . . . . . . . . . . . 27

1. General Undervaluation of Hydroelectric Power by Government

Decision Makers . . . . . . . . . . . . . . 27

2. Wheeling .......... . . . . . . . . . . . . . 27

3. Recreational Requirements . . . . . . . . . . . . . . 29

4. Fuel Adjustment Clauses . . . . . . . . . . . . . . 29

5. Feasibility Analysis . . . . . . . . . . . . . . 29

B. Minor Incentives . . . . . . . . . . . . . . . . 30

1. Early Contact with Environmental Groups . . . . . . . . . . 30

2. Peaking-River System Management . . . . . . . . . . . 31

3. Energy Employment Acts . . . . . . . . . . . . . . . . 31

4. Early State Review . . . . . . . . . . . . . . . . . 31

5. State Energy Offices . . . . . . . . . . . . . . 32 
Program in Social Management of Technology University of Washington

I. INTRODUCTION ............................. 33

II. SUMMARY..................................... 34

The Sites and Their Developers ........................ 35

Impediments, Conclusions and Recommendations ............... 35

Incentives, Conclusions and Recommendations . . . . . . . . . . . . . . . 37

III. CASE STUDIES .............................. 38

A. South Columbia Basin Irrigation District, Pasco, WA. . . . . . . . . . 38

The Small Hydropower Sites . . . . . . . . . . . . . . . . . . . . . 39

History/Background of Small Hydropower Development ............. 40

The Partnership for Development ................... 43

Agreement for Power Purchase ........................ 45

Lessons of the Case Study .......................... 46

B. Bull Run Hydroelectric Project, Portland, OR. . . . . . . . . . . . . 54

History and Description of the Site ................. 55

Background of the Project ........................ 58

The Power Purchase Agreement ....................... 61

Lessons of the Case Study ... . . . . . . . . . . . . . . . . . . 62

Appendix A

Estimated Capital Costs for P.E.C. 22.7 ... . . . . . . . . . . . . . 69

Appendix B

Estimated Capital Costs for Bull Run Sites . . . . . . . . . . . . . . . . 71 


\section{INTRODUCTION}

This Executive Summary consists of a distillation of the observations, conclusions and recommendations developed from the completion of five (5) case studies of hydroelectric sites in the States of Georgia, Michigan, Wisconsin, Maine and Pennsylvania. The work was accomplished by the Energy Law Institute of the Franklin Pierce Law Center, Concord, New Hampshire for the National Conference of State Legislatures.

The Energy Law Institute was founded in 1978 to perform a two year contract with the Department of Energy (DOE), to identify and analyze the legal and institutional barriers and incentives to hydroelectric development in the 19 northeastern states. This project includes the development of a systems dynamics model, of hydroelectric development with the Thayer School of Engineering in Dartmouth College. The Institute has prepared separate reports on each of the nineteen states, several reports on the federal system and a number of special reports on economic and legal issues of particular importance to hydroelectric development, and energy law and policy in general. The Institute now performs legal, institutional and policy analyses on a wide range of energy issues and provides advice and information to regulators, legislators and developers.

The Institute employs a full time professional and administrative staff, including five lawyers and an academic micro-economist. All of the staff have direct experience in government regulation. The director, Professor Peter Brown, has practiced law on Wall Street, served as First Attorney General for the Commonwealth of Pennsylvania and Chief Counsel to the Pennsylvania Public Utility Commission. Professor Brown is a full professor at Franklin Pierce Law Center and teaches courses in Econornic Regulation and Civil Procedure. The case study supervisor, William Wilson, is an attorney with experience in economic regulation, administrative and municipal law. The case study student research team included four senior law students and a beginning MBA student with substantial practical business experience. Two of the law students 
have prepared and supervised other students in the preparation of some of the Institute's DOE hydro contract work. The other students have professional experience in chemistry and microbiology. Professor Brown and Mr. Wilson may be contacted directly for any questions or comments regarding this study at the Energy Law Institute of the Franklin Pierce Law Center, Conçord, New Hampshire 03301. The telephone. number is (603) $288-1541$.

The material contained here is, in part, a summary of the five separate reports on the legal and institutional barriers and incentives bearing on the development of each site. It is also a summary of the cumulative impressions of the actual general legal and institutional climate for small-scale hydro electric development represented by the issucs confronting cach site.

The purpose of this document is to provide a general analysis and overview of the significant problems and opportunities for the development of hydroelectric facilities identified in the five full reports. For reasons of economy, citations to statutes, regulations and case law are omitted here, except where necessary for an understanding of the executive summary. Interested parties should consult the full reports for an expanded discussion and documentation of the information presented here.

Neither this document, nor any of the full case reports is intended to provide a detailed explanation of the federal regulatory systems or any of the state systems. That information is contained in other publications prepared by the Energy Law Institute for the U.S. Department of Energy. Inquiries may be directed to the Institute or the Department of Energy in Washington, D.C. Additionally, this summary and the full reports are not intended as legal reference works for the development of small hydroelectric facilities. Specific questions on actual legal controversies involving small dams should be referred to attorneys.

The material contained in this report is based on case studies of hydroelectric sites at the following locations: 
1. High Falls, Georgia - under consideration by the Georgia Department of Natural Resources;

2. Traverse City, Michigan - being developed jointly by Traverse City Light and Power and Grand Traverse County;

3. Swanville Lake, Maine - being developed by Lawrence Gleeson;

4. Cornell, Wisconsin - developed by Northern States Power Company of Wisconsin and

5. Maxwell Locks, Pennsylvania - being developed by Allegheny Rural Electric Cooperative.

The case selection was based on a desire to consider the special problems of five different types of hydroelectric developers: a state agency, a municipal electric department, a private entrepreneur, an investor-owned utility and a rural electric cooperative. These selections were able to benefit from and build upon extensive background research on the legal aspects of hydroelectric development, resulting from previous Institute activities. The specific selections were based on particularly interesting features about each development identified in feasibility study summaries or previous experience with the development.

The studies were initiated with an examination of feasibility reports on the sites, a research of the legal factors bearing on each state and preliminary telephone communications with the developers and other interested parties. The developers, regulators, legislators, environmental groups and interested local residents concerned with each project were then interviewed in a series of on-site visits performed by a team consisting of the Project Supervisor, a business student and one or more law student researchers. Where appropriate, federal regulators and hydroelectric development principals were also interviewed.

The vast amount of data collected was sifted, analyzed and supplemented with additional research to produce the draft case reports. The draft reports were then 
reviewed by Energy Law Institute staff and forwarded to distinguished experts in the field of hydroelectric power, who comprise the Institute's Advisory Committee, for review and comment. Finally, the staff and Advisory comments and further research results were synthesized into the final case reports and in the executive summary. .

This report is organized into four major sections. The first section summarizes the major general conclusions and recommendations derived from an analysis of all of the cases. This section is divided into obstacles and incentives to hydroelectric development. The second briefly describes the cases analyzed for this report. The third elaborates upon findings on the major barriers and incentives introduced in Section One. The fourth section discusses the minor obstacles and incentives to hydroelectric development and suggested changes.

The priorities of the findings are based on an assessment of their relative significance to hydro development in general, as well as the projects in which they are identified, the expected duration of their influence, their amenability to legislative action and the depth of information about their cause and effects.

\section{A SUMMARY OF MAJOR CONCLUSIONS AND RECOMMENDATIONS}

The problems associated with hydroelectric developments are extremely site specific. This complicates, efforts to isolate the most significant obstacles and incentives to that development. Nevertheless, it is possible to set priorities for the development factors identified in the case studies according to the criteria discussed in the first section of this report entitled Introduction. The following conlusions and recommendations are considered particularly significant. As noted in the Introduction, a more thorough discussion of these factors, including the context in which they were discovered, is contained in Section IV. 


\section{A. Major Obstacles}

The delays, redundancies and contradictions endemic to the dual licensing of hydro projects under FERC jurisdiction substantially discourages hydro development. Either the states, or the FERC, should be vested with responsibility for a particular concern, such as fisheries or wildlife protection. A hydro developer's access to information about licensing and environmental implications should be increased through improved and more readily available publications, counseling staff and public information releases.

State legislatures should formulate specific guidelines to enable state DNRs and other regulators to achieve a balance of energy and environmental concerns in hydro permitting decisions consistent with the public interest. The total implications of hydroelectric development should be considered.

Statutory and regulatory fish ladder requirement standards should be re-evaluated in light of their impact on hydro development, their effectiveness, fish management alternatives, changing social priorities and desired cost allocations. Specific legislative guidelines are needed here.

The U.S. Army Corps of Engineers employs a consumptive use formula for assessing water storage fees at Corps' multi-purpose dams which increase the costs of developing such projects to the point of discouraging full utilization of much of this valuable energy. The Corps' storage fee determination should be revised to comport with the non-consumptive characteristics of hydroelectric generation and current energy policies.

Most hydroelectric projects must pass through a federal and state licensing process which provides multiple opportunities for harassment through intervention. Protracted intervention can substantially increase development delays and expense, and may even prevent some projects. Hydroelectric licensing intervention guidelines 
should be modified to reduce opportunities for redundant objections and non-productive delays.

\section{B. Major Incentives}

Environmental mediation offers substantial promise for reducing the opposition to certian hydroelectric projects. Its use should be encouraged.

Feasibility grants and forgivable loans serve a desirable purpose in enabling developers to discover potential valuable hydroelectric sites which might otherwise go unnoticed. They should be continued.

Hydroelectric development is highly sensitive to loan interest rates and availability. Current municipal bonding advantages should be preserved and refined, and low interest loan programs for private developers should be expanded. Certain tax and security law exemptions would further improve financing and development prospects for private developers.

The Public U'tility Regulatory Policies Act of 1978 (PURPA) contains provisions which stimulate private hydroelectric development by guaranteeing a market and a reasonable price for power produced at small independent hydroelectric facilities. To ensure its optimal impact, State PUCs and developers should be fully apprised of its terms and effects. FERC regulations or legislative amendments should clarify certain uncertainities about when a utility may be compelled to enter a contract with a small producer and the permissability of so-called fuel future contracts.

The FERC's recently reduced licensing requirements for existing dams appears justified in terms of environmental impacts and its valuable up-front cost reduction benefit to small hydroelectric developers. To insure maximum positive impact, state permitting agencies should adopt comparable standards. 


\section{THE CASES}

A. High Falls, Georgia

The proposed High Falls project involves the development of one of four potential power plant sites located on Towalega River within the High Falls State Park in Monroe County, Georgia. Of the four sites considered in the project feasibility study, the old power house was judged to be the most attractive location for development. The old power house site offers a 110 foot head which would enable an installed capacity of 2.1 megawatts with very little environmental disruption. The levelized cost of energy from the site was estimated to be a very attractive 12 mills (approximately 1.2 cents per kilowatt hour).

The High Falls site was first harnessed for power in 1898 with a four foot dam and 2,000 foot canal. In 1904, the existing 35 foot stone and motor dam was completed and penstocks were installed at the end of the canal to enable generation by three turbines within the old power house. Power was used for a nearby cottonmill and town. The site was purchased by a utility and used by Georgia Power Company until 1958 when the equipment was removed. Title eventually passed to the Georgia Fish and Game Department as part of a donation of land which became the High Falls Park.

Interest in restoring the hydroelectric capability of the site was stimulated by the award of a Department of Energy (DOE) Program Research and Development Announcement Grant (PRDA). The resulting study was conducted by the Georgia Institute of Technology's Experiment Station and the Cadre Corporation, and managed by the Georgia Office of Energy Resources. The study concluded that project was technically, environmentally and economically feasible and that the old power house site (not officially studies because its 110 foot head exceeded PRDA grant limitations) offered the best returns.

At present, the site is part of the park managed by the Georgia Department of Natural Resources. While the DNR cooperated with the Georgia Energy Office in 
applying for the PRDA grant, it has some reservations about entering the hydroelectric generation business, particularly at one of its parks. The DNR's pursuit of this development is hampered by a lack of incentive (the DNR has nothing to gain from project revenues), a built in conflict between power project objectives and the recreational and environmental values the DNR is charged with protecting, and a lack of clear values the DNR is charged with protecting, and a lack of clear statutory authority to engage in such a development. The prospects for development by another party are correspondingly limited by the lack of a state policy on the disposition of state owned hydroelectric sites and the absence of an easy procedure for passing title to such sites to an appropriate development authority.

The old power house at High Falls is an example of an excellent hydroelectric site. The existing civil works, good river flow and head size enable a highly competitive cost of electricity. Built-in deed restrictions prohibit impoundment fluctuation and the projected run of river operation is not expected to cause any significant negative environmental impacts. If the project can be profitably and expeditiously developed within the park with a minimum of negative impacts, it should serve as a useful guide to hydroelectric facility siting in the state. While DNR would not seem to be an appropriate developer, the project could be transferred to another state entity, the Municipal Electric Authority of Georgia (MEAG), with both the authority and incentive for such a development. In addition to its authority and incentive, the MEAG has a transmission agreement with Georgia Power Company which would facilitate the wheeling (transmission) of power from the project.

At this point no decision has been made to pursue development. However, the MEAG has expressed an interest in the site's potential.

B. Boardman River, Michigan

The Boardman River project consists of a proposal to renovate a five dam system 
on the Boardman River near Traverse City, Michigan. The five dams range from 9 to 41 feet of head, with impoundments of up to 191 acres. One of the dams (20 foot head with a forner 12 acre impoundment), was washed out in 1961 and all remnants of the prior construction have been removed. The Boardman River offers a good, relatively stable stream flow. A recent feasibility study indicated a number of development options with estimated energy output and costs from 2,290 kW at 23 mills per $\mathrm{kWh}$ to 2,980 at 43 mills per $\mathrm{kWh}$, depending on the number of dams restored.

All of the five dams have been previously used for generating electricity, the first beginning in 1894. Since that time, three of the dams have been retired and their generating equipment removed (the last in 1969), and one dam was washed away (1961). One dam continues to generate power for one of the proposed developers, Traverse City. Light and Power. The Boardman River has been classified a first class cold water stream by the Michigan Water Resources Commission. Its water quality meets or exceeds all established stallar is for the river basin. The upper parts of the river offer excellent habitat for brook and brown trout which was resulted in the river's classification as one of MIchigan's top ten trout streams. The Boardman proposal was presented as a joint venture of the Traverse City light and Power Department. (TCL\&P), and Grand Traverse County, Michigan. The feasibility study was also funded by a PRDA grant, which contributed substantially to the developer's immmediate interest in the project. The county owns two of the dams, while the city owns the remaining three, including the one washed out. The county's initial interest in the project grew out of a dam safety inspection conducted by the engineering firm that eventually prepared the feasibility study. The county now hopes to derive a continuing stream of revenues from its dams. TCL\&P is an experienced, professionally managed municipal electric company which currently operates a hydroelectric plant at the largest of the five dams. TCL\&P is facing an increasing power demand and views the 
project as an economical long range hedge against the rising fuel costs of fossil fueled plants. Neither TCL\&P nor Traverse County have ever developed a hydroelectric project.

The prospects for the eventual success of the Boardman project are marred by a number of problems. The major and most controversial problem centers around the probable requirement for fish ladders at the dams to convert parts of the river to an anadromous fish hatchery. If installed, the ladders are estimated to increase the restoration costs by nearly 45 percent. Additionally, local residents are strongly opposed to the installation of fish ladders or the introduction of anadromous fish to the river. Restoration of the washed out dam will also be hampered by the more stringent licensing requirement for new dams, at both the state and federal level, as, well as substantial independent environmental opposiiton. It should be noted, however, that the high costs of such a complete restoration would not make it feasible without a substantial relative increase in fuel costs. Finally the developers have encountered some difficulty gaining access to information and expertise that would facilitate the licensing of the project. Licensing difficulties appear to have been underestimated and initial contacts with the state DNR have not been encouraging. On the positive side, as a municipal developer, the joint venture will be able to benefit from the reduced financial costs made possible by the availability of tax exempt municipal revenue bonding.

There have been no final decisions made on development, but the joint venture is currently pursuing state and FERC licensing.

C. Swanville Lake, Maine

The Swanville Lake project is comprised of a series of five dams located on the Goose River near Belfast, Maine. The dams range in size from 6 to 31 feet of head. The restoration calls for the installation of turbines in four of the dams, and the use of the remaining dam ( the first in the system) to regulate flow through the system. While 
all of the dams will require some degree of renovation and new construction, their relatively good condition has helped keep development costs quite low. The developer's sweat equity has also contributed substantially to the low costs ( the developer is involved in a joint effort with a local foundry to develop a new inexpensive turbine and the project is expected to yield a total of $430 \mathrm{~kW}$ of installed capacity at a cost of approximately $\$ 800$ per $\mathrm{Kw}$.

Four of the five dams had previously been used to generate electricity. One had been used only with a waterwheel. While most of the equipment has been removed from these sites, the remaining equipment is usable, an economic advantage which contributed to the developer's initial interest in the sites.

The project is being developed by Maine Hydroelectric Development Corporation (MHDC), a thinly capitalized entity whose principle asset is its founder, Lawrence Gleeson. Mr. Gleeson, a former systems planner for Sun Oil Company, acquired the rights to the site for MHDC in 1977. The feasibility of the site was independently analyzed at very low cost by Mr. Gleeson. Since he has been involved in other hydroelectric projects, Mr. Gleeson is conversant with the legal requirements of licensing. Mr. Gleeson's expertise and the fact that the proposed partial peaking use of the system is expected to cause no major environmental damage, enabled the project tos virtually bypass the state licensing process. Mr. Gleeson enjoyed somewhat less success; with the FERC process, but has managed to surmount all difficulties, including a determined intervention by local residents.

The intervention in Gleeson's FERC licensing process grew unt of the concern of property owners about lake level fluctuations on the storage reservoir for the MDHC system. Despite Gleeson's absolute legal right to fluctuate the levels on this lake (Gleeson's property acquisition included all riparian rights around the lake), the project was threatened by a violent and tenacious public opposition that prompted the FERC to 
encourage Gleeson to engage in a form of environmental mediation with the local residents. The mediation yielded a compromise fluctuation schedule and MHDC is awaiting a final FERC decision.

The project was also hindered by MHDC's lack of capital. Local financing institutions were reluctant to risk the large sums needed for a hydro project without some better security. However, Mr. Gleeson was finally able to secure project financing by obtaining a 20 year power sales contract with Central Maine Power Company (CMP) for a price of about 36 mills with rertain escalator provisions. CMP has a history for fair treatment of small hydro power sellers and both parties appcared pleased with the contract.

\section{Maxwell Locks, Pennsylvania}

The Maxwell Locks proposal calls for the installation of generating equipment at a U:S. Army Corps of Engineer's (Corps) navigation dam on the Monongahela River above Pittsburgh, Pennsylvania. The Maxwell Locks and dam were constructed in 1965 to replace an older dam and locks at that location. The Maxwell locks and dam are part of a nine lock system which enables large industrial coal barges to navigate the Monongahela. The river is also subject to heavy consumptive use demands which limit the marginal water avajlible at the site (water beyond that necessary for lock operation). The proposed development would be a run of the river operation consisting of four two megawatt ( $\mathrm{mW}$ ) turbines. Costs of energy frnm the site is estimated at $\$ 1,759$ per installed $\mathrm{kW}$.

The Maxwell site was also the recipient of a PRDA feasibility grant. The PRDA application was filed by the intended developer, Allegheny Electric Cooperative (AEC), a wholesaler to 14 member rural electric cooperatives. AEC currently buys the bulk of its power from the Power Authority of the State of New York (PASNY) and West Penn Power Company. There is some question about the continual availability of the low cost PASNY power which, coupled with ACE's forecast increased electric demands, 
has prompted AEC to become a generation cooperative. AEC views the Maxwell project as a part in its overall generation development scheme.

The proposed project appears likely to avoid serious environmental objections and be able to meet state and FERC licensing requirements. Nevertheless, the developrnent has encountered a number of obstacles which render its future questionable. Initially the developers experienced some difficulty obtaining necessary inforınation about the state and FERC process, wheeling and the special implications of development at a Corps dam. While the feasibility study found the site marginally feasible, its feasibility depends on low interest money which may not be available from the Rural Electrication Administration (REA). Additionally, the REA imposes a 10 year best alternative comparison limitation on all cooperative projects which would preclude a developmerit at Maxwell Locks. The FERC's first year net benefits test for use of water at governinent projects would also' seem to prevent the project from continuing since AEC has no distribution network at the dam, it must arrange to transmit or wheel power from the site over a neighboring utility's line. The rates suggested by that utility would make the project infeasible, and while in conformity with industry conventions; are probably much higher than cost of service regulation would dictate. Finally, while not applicable to the Maxwell project, examination of Corps storage fee procedures revealed a formula that would kill most small hydro projects at Corps' dams. AEC has not yet decided to proceed with development.

\section{E. Cornell, Wisconsin}

The Cornell site is a 38 foot head, $30 \mathrm{~mW}$ facility located on the Chippewa River near Eau Clair, Wisconsin. It was developed in 1975 at a cost of $\$ 500$ per $k W$ installed, which is clearly a bargain at today's prices. The plant consists of three $10 \mathrm{~mW}$ units and one small $750 \mathrm{~kW}$ unit included to take advantage of the minimum flow discharge requirement. The facility is used primarily for peaking purposes and its performance is enhariced through tandem operation with a $34 \mathrm{~mW}$ facility situated upstream and owned by the same power company. In fact, the developing company has three other 
hydroelectric projects on a 58 mile section of the Chjppewa which enable a coordinated maximum economic utilization of the water from the system's two storage impoundments.

The dam at Cornell was initially constructed in 1903 for use in milling, manufacturing and hydraulic purposes. It was acquired in 1931 by the developer, Northern States Power Company of Wisconsin (NSP), an investor-owned utility. The prior owner continued for its paper products processes, under a lease arrangement, until 1971. At that time, NSP began seriously considering redevelopment. NSP completed a series of internal feasibility studies which culminated in a 1972 decision to file for a FERC license.

The developer, NSP, is a tütally uwned, subsidlary of Northern States Power Company of Minnesota. It is one of seven major investor-owned utilities in Wisconsin and operates generation transmission and distribution facilities in the west central part of the state. NSP is interconnected with its parent, physically and through management and cost sharing arrangements which lower NSP's costs. NSP currently generates power primarily with oil fired, gas turbine peaking units (75\%) with a substantial amount provided by hydroelectric dams (75\%). The company purchases most of its power from its Minnesota parent ( $80 \%$ ) and from Manitoba Hydro and the Western Area Power Administration. The Cornell facility was developed to help meet NSP's pressing need for generating capacity to meet projected summer peaking demands. The hydro facility was compared with an equivalent size gas turbine unit and found to require smaller revenues over a 35 year period. In fact, the 1972 decision proved to be an excellent hedge against fuel cost increases and by 1976 the Cornell project was estimated to provide average savings of over $\$ 500,000$ over a gas turbine.

The Cornell project experienced virtually no problems with state and FERC licensing. NSP's success at the state level was largely attributable to its constructive and enlightened environmental attitude and its history of honest and harmonious 
interaction with the Wisconsin DNR. NSP approached each aspect of the development with a willingness to engage in up-front negotiations and cooperation. This enabled it to maintain a constructive dialogue with all affected regulatory agencies, which undoubtedly expedited the granting of the license. There was no intervention and the FPC (now the FERC) license was granted in 1973. The plant was fully operational in 1976.

\section{MAJOR OBSTACLES AND INCENTIVES TO HYDROELECTRIC DEVELOPMENT AND RECOMMENDED ACTION}

A. Major Öbstacles

1. Delays, Contradiction and Redundancy in the Licensing Process

Since most potential hydroelectric sites must be reviewed at both the state and federal levels, there are multiple opportunities for regulatory overkill. The cases examined confirmed this expectation and indicated that the hydro licensing process is one of the most significant disincentives to hydroelectric development. Every case revealed some degree of licensing difficulty, attributable in great part to the overlapping of federal and state jurisdiction over hydroelectric development.

Despite the best efforts of state and local regulators, the success of interaction between the Federal Energy Regulatory Commission (FERC) and state agencies appears highly variable. The cases studied revealed near polar extremes of complementary interface. Despite a history of reasonably smooth federal-state hydro licensing cooperation, the prospects for an intergrated licensing process in Michigan appear slight. State Department of Natural Resources (DNR) personnel expressed reservations about the appropriateness of FERC permitting standards for Michigan purposes, and have no intention to mirror FERC's recent regulations reducing the application burdens for projects at existing impoundments. In contrast, the Wisconsin DNR accords considerable deference to federal review of FERC licensed projects, generally declining to require separate state approval on subjects about which the FERC allows state 
comment. The department's FERC coordinator is highly active and has demonstrated a willingness to assist hydro applicants in completing required FERC exhibits. Naturally the differences between state and federal objectives dictate that the duality of the hydro licensing system be preserved to some extent. However, the actual, and perhaps more importantly, the perceived burdens of the dual system on developers are heavily dependent upon the extent to which federal and state agencies actively attempt to avoid permitting requirements that can be satisfied by the other system. The studies confirmed this since the fewest licensing problems were noted where, as in Wisconsin, state regulators confined their review of FERC projects to commenting on the FERC application.

The cases studied also revealed considerable variability in the extent to which the state licensing systems promote a fair and efficient evaluation of a proposed hydroelectric project. For the most part, a hydro applicant must satisfy the diverse and potentially conflicting interests of a variety of state regulatory agencies, which may not have established formal coordination or conflict resolution procedures. In Pennsylvania, for example, an applicant must deal with the Bureau of Dam Safety, the Bureau of Water Quality and the Fish Commission, any one of which can independently postpone or delay a project. Even more disturbingly, the recently adopted Maine onestop hydro licensing process does not appear to cover all potentially interested state agencies and has jurisdictional components that limit its utility (not available to existing dam projects above $1.5 \mathrm{mw}$, or any project not requiring one of four specified permits). Gerogia, however, has a comprehensive review division within its DNR which selects and coordinates the responses of interested DNR divisions under the federal assisted program review process (A-95 review). The comprehensive review division is also informally available to coordinate processing of hydro applications and could be easily invested with lead authority to consolate and expedite DNR division responses. In a similar vein, the Michigan DNR has an informal process for internally resolving inter- 
departmental permitting deferences (such as the different minimum flow dictates of Water Quality and Fisheries), which could be formalized into a true one-stop system.

Hydroelectric development could be substantially encouraged by reducing the redundancies in the licensing process. State legislatures could eliminate state permitting requirements on projects subject to FERC jurisdiction, limiting state regulatory input to the FERC process. Congress could also authorize FERC to enter into compacts with state regulators to eliminate federal review of matters resolved at the state level. The first approach facilitates a uniform national hydroelectric development policy while the second augments state control of hydro development. One or the other is vitally needed.

To the extent state permitting is retained, a streamlined process should be encouraged. Some type of one-stop licensing procedure seems desirable, but care must be taken to insure that the coordinating agency has the responsibility, authority and staff to shepherd all applications. Departmental review deadlines are strongly recommended. Failure to meet these deadlines should result in clearance by the offending authority. Among the case study states, Georgia's Comprehensive Review would seem the most readily adaptable. Michigan's revised processing scheme also appears to be a step in the right direction.

\section{Informational Deficiencies}

Virtually, all of the developers will experience unnecessary development delays and costs resulting from difficulties in obtaining information necessary to determine the licensing requirements facing their project.

The Michigan and Pennsylvania studies offer good examples of these problems. At the time contacted, the Michigan developers exhibited very little knowledge about state and federal permits and their implications for the proposed project. The Pennsylvania developers appeared similarly uninformed and had made incorrect or imcomplete assumptions about the legal and institutional facets of development at 
Corps of Engineer dams and marketing or wheeling. While much of the needed information is available from state and federal regulators, access is limited by mistrust and a general lack of knowledge about the value of particular information at various stages in the projects. Most new developers appear to underestimate the impact of regulatory and environmental obstacles on project feasibility.

The remedy here seems to indicate increasing the availability of information about hydro development requirements and improving the comprehensibility of the information provided. License requirements and possible environmental concerns could be capsulized into check list form. State agencies, such as state energy offices and DNR's could be staffed and directed to provide specific counseling and assistance on project evaluation and licensing issues. Potential developers should be educated about the desirability of acquiring accurate and complete development information early in the process of considerating a specific project.

\section{Absence of State Hydroelectric Development Policies}

The lack of a comprehensive state hydroelectric program was found to retard hydro development in at least two ways. The Georgia case illustrates the problem of state ownership of an attractive hydroelectric site with no plan or simple procedure for transferring such a site to a state or private entity with the means and incentive to develop it. The Georgia study project is located within a state park administered by the state DNR. The DNR has nothing to gain from development and is further hampered by a lack of expertise and operational authority and a built-in conflict of interest over use of the property. The current mechanism for transferring such property to other owners is cumbersome and the inclination to pursue such a transfer is impeded by the absence of any state policy on the utilization of state owned hydroelectric sites. The Michigan case illustrates the difficulties a developer may expect in meeting DNR environmental priorities in the absence of clear legislative hydro policy guidelines. Since the Michigan DNR's direction on hydroelectric projects is governed largely by language in competing 
special purpose statutes (for example, the Fish Passage and Natural Rivers Acts), which provide it with jurisdiction over such development, it should not be surprising that hydroelectric potential is undervalued relative to the other resource priorities the DNR is specifically charged with protecting. While the Michigan DNR's current informal preference for dam breaching and optimal recreational facility requirements may be appropriate given its current broad statutory mandates, it would seem that the DNR's position represents an evaluation of the relative value of an important state resource (hydroelectric potential) that the legislature is best equiped to provide.

These two examples should illustrate the importance of a comprehensive state hydroelectric development policy. State agencies hold title to a substantial number of developable hydroelectric sites. State legislatures should decide the circumstances under which these sites are to be developed, and by whom, and provide simple mechanisms for insuring that development. The state permitting of hydroelectric facilities raises fundamental public policy issues, such as the appropriate balance to be achieved between energy needs and specific environmental concerns. State legislatures should provide their DNR's with specific guidance on how the relative energy value and environmental implications of competing energy sources should be evaluated. In formulating these guidelines, legislatures should consider all impacts of hydro development, such as the possibility for reduced environmental damage of a potentially more serious nature from competing energy sources and the opportunities for mitigating hydro environmental problems. Maine's new licensing act mandates consideration of fuel replacement values in licensing decisions. This represents a good start, but more comprehensive instructions are desireable.

\section{Fish Passageways}

The probable requirement of fish passageways at the proposed Michigan project was clearly the most controversial aspect of the Michigan case study. The Michigan DNR insisted that fish ladders are mandated under the state's jong standing Free 
Passage of Fish Act and necessary for the utilization of the river as an anadromous fish spawing stream for the Great Lakes. The developers objected that passageway installation would appreciably increase project costs (between 35 to 100 percent including water loss, depending on the dam), and raised questions regarding the effectiveness of such devices. (This concern is apparently shared by some fisheries' experts since the Wisconsin and Maine DNRs expressed considerable doubt that ladders were cost effective). Residents in the areas surrounding the dams fear that the ladders will admit PCB, and other contaminated lake fish into their relatively clear river, and attract crowds of salmon fishermen with an attendant threat of property destruction. State trout fishermen oppose the ladders because they believe the introduction of anadomous fish will jeopardize the well being of the river's current trout population (the river is considered one of the state's best brown trout streams). In short, the ladder requirement raised a number of technical and policy quandries regarding proper fish management techniques and state resource priorities.

Although they constitute a threat to only one of the projects considered, fish passageways must be viewed as major hydro development obstacles. Where required, their cost can easily render an otherwise feasible project infeaslble. Fish laddei installation which promotes a particular species may be extremely controversial. Furthermore, their effectiveness is greatly debated. In view of fish ladders' potentially stifling impact on hydroelectric development, state legislatures should reconsider the resource management and societal priority policy issues raised by the ladder question, then formulate specific guidelines for requiring their installation on existing dams. The wisdom and fairness of DNR policies which limit ladder requirements to dams targeted for hydroelectric retrofitting should also be questioned. Finally, the availability of fish management alternatives should be considered, and options for assessing the costs against the fishermen or citizens who would benefit most directly from this requirement should be explored. 


\section{FERC User Fees and U.S. Army Corps of Engineers Water Storage Fees}

The unused hydropower potential of federal dams could make a significant contribution to total energy needs. The Pennsylvania study dealt with a rural electric cooperative's plans to utilize the extra water at Corps' navigation dams. At least two impediments were found to face private developers attempting to harness unused federal dam power.

FERC user fees reduce the return from private hydro developments at federal dams, but the formula for their calculation protects against rendering the project infeasible. Unfortunately, the same formula requires a calculation of net benefits over power alternatives during the project's first year. The Pennsylvania project studies would be rejected under this test. Such an approach will prevent development of projects with initial negative benefits which become highly cost effective over the project life. User fees should be redesigned (FERC is considering changes) to reflect the costs and benefits to all parties of the development. The first year net benefit approach should not be used to determine project feasibility.

The Corps has a statutory responsibility to assess fees against any party making use of water storage at a Corps multi-purpose dam. The proposed Pennsylvania project involved a single purpose navigation dam with no planned water storage, and hence would not be subject to such fees. However, since many unused water projects would trigger a storage assessment and the amount of such fees promise to be a large portion of such.federal dam development this problem merits examination. The Corps has no specific guidelines for assessing hydroelectric storage uses, but currently feels obligated to utilize a formula devised for. consumptive users which would render many valuable hydro projects infeasible: This formula should be revised to reflect the differences in hydroelectric storage utilization and current energy priorities. ?

6.: : Intervention

Hydroelectric projects, which usually must pass through both state and federal licensing processes, present easy targets for multiple interventions. Most of the cases 
studied indicated a strong possibility of intervention at both the state and federal levels. The Maine case illustrates that the strength of a developer's legal rights offers little protection against the licensing delays and costs attendant to combating a determined intervention effort. While certainly the objections of affected parties should be considered, some cut-off appears to be needed. Intervention may substantially increase project costs and delay approval.

Legislatures should consider adopting intervention guidelines which preclude interventions that raise issues previously addressed. The FERC should not allow interventions by parties who had the opportunity to raise objections during state permitting. The guidelines should include filing and hearing timetables which are strictly enforced.

\section{B. Major Incentives}

1. Environmental Mediation

Based on the experiences in the Maine case, the use of environmental mediation techniques may significantly promote hydroelectric development. The single, most common local objection to hydroelectric development concerns the kind of lake level fluctuations that were at the core of the Swanville Lake controversy. Impoundment fluctuations enable a hydro facility to produce peaking power, the most highly valued type. These fluctuations also cause obvious problems for lakeside owners. At the Swanville site, the environmental mediation process enabled local resident to obtain a comfortable forum for their concerns, and apparently contributed to an increased understanding of opposing positions which rendered compromise possible. The resulting settlement will save both sides much in costs and delays.

This process could be of value in resolving related environmental disputes at hydro sites. It should be encouraged as an alternative to intervention or other legal action. For instance, the FERC or a state regulator could require evidence of a bona fide attempt at mediation as a condition for granting intervenor status. The state or federal government might also underwrite some of the costs of the mediation. 


\section{Feasibility and Licensing Grants and Loans}

The feasibility grant was a substantial incentive in all of the cases where it was available:

The Georgia and Pennsylvania sites would probably have not been examined in the absence of some up-front money incentive. The Michigan developers were independently considering an examination of their sites, but the availability of the PRDA feasibility grant accelerated the process and encouraged a joint county-city submission. The impact of these grants is not surprising in view of the high costs of feasibility analyses $(\$ 96,000$ for the Boardman study). Unexperienced developers are understandable relunctant to risk such sums at such an early point in project assessment. Consequently, the availability of such grant money, and of comparable forgiveable feasibility and licensing loan programs, appears to serve a valuable function in facilitating the identificaton of attractive hydro development candidates which might otherwise remain unnoticed. These programs should be retained or expanded, and supplemented with equivalent or matching state assistance.

\section{Financing and Tax Incentives}

Since hydroelectric generation is highly capital intensive, the availability of low cost loan money is a prime concern to all hydro developers. The cases examined clearly reveal the sensitivity of project feasibility to seemingly trivial differences in loan interest rates. The financing community still has some reservations about the risks of backing thinly capitalized private developers.

The nature and extent of financing concerns depends greatly on the type of developer. The Georgia and Michigan studies confirmed that public developers, such as municipalities, benefit from an established bonding history, the ready availability of municipal financing specialiasts, and, most importantly, the reduced interest rates made possible by the bonds' tax exempt status. These advantages must be preserved if extensive municipal participation in hydro development is desired. Current federal tax limitations on the tax exempt status of bonds used to fund electric projects for ultimate 
sale to non-public entities should also be re-examined.

Private developers generally have more difficulty acquiring funding and are faced with the highest interest rates. The Maine study reflects this. The Public Utility Regulatory Policies Act (PURPA) helps by attempting to guarantee a market for power from private sites, but many lending institutions are reluctant to risk any funds until a firm power sale contract is secured. Private hydro developments are, however, well suited for limited partnership tax shelter arrangements and frequently offer the prospect of a good investment return. Legislatures can help by preserving and expanding current tax advantages, funding construction loan programs, providing financial counseling for potential private developers and creating security law exceptions to encourage local investment brokers to consider marketing hydro investment packages.

\section{Public Utility Regulatory Policies Act of 1978 (PURPA)}

PURPA was intended to help stimulate small alternative energy projects, including hydroelectric developments. Its provisions, enabling small producers to compel utilities to purchase their power at rates set by state public utility commissions (PUCs) should guarantee a market for the power from those facilities. Its rate setting standards, mandating a value of service approach based on the incremental costs of energy replaced, should insure a fair price for that power. Hydro development should be encouraged by the reduced risks of marketing, the enhanced bargaining power in price negotiations with utility buyers, and the pricing parameters established by the rate standards.

PURPA regulations have not been implemented, but some effects are already noticeable. The Georgia and Maine cases suggest that PURPA will prompt utilities to be more flexible in price negotiations with hydro developers. While there were not any difect admissions of this, the price discussions in those negotiations reflected a substantial departure from previous utility bargaining postures on purchases from small 
hydroelectric facilities that could best be explained as an anticipation of PURPA forced purchases. Nevertheless, some additional efforts will be required to insure that the benefits of PURPA are fully realized.

As mentioned earlier, private developers frequently need a signed power contract to attract project financing. The Maine developer could not have proceeded without such a contract. PURPA provides that utilities may be required to purchase the power $\because$ from such facilities, but it does not specifically enable small power producers to secure a power contract prior to making that power available. PURPA should be clarified through amendment or regulation to enable the utility to be compelled to enter into a firm contract with the developer at some earlier point in time, perhaps after receipt of a FERC license.

Additionally, hydro developers would benefit from a federal PURPA modificaiton defining the time frame over which the "not to exceed incremental cost" standard should be applied. The Maine mini-PURPA offers a useful model, by expressly authorizing a project life time frame. "This enables the developer to secure a frequently desired "futures contract" in which energy payments may exceed utility incremental costs during initial years, but fall below utility incremental costs in later years of the contract. This modification should be implemented.

Finally, the studies indicated that developers and state regulators are extremely unfamiliar with PURPA opportunities and implications. The Maine, Wisconsin and Pennsylvania PUC staff persons contacted expressed views on PURPA which ranged from a lack of knowledge about the legislations' general thrust to an assumption of negligible impact on current PUC policies and responsibilities. The Maine developers expressed fears that PURPA would poison the utility industry against small hydroelectric producers and vowed to attempt to avoid its influence. Both represent significant problems, since developers can make little use of a bargaining tool they do not fully 
understand and regulators cannot be expected to deal with intricacies of which they are not aware.

Resolution of this problem seems primarily an educational task. However, clear and comprehensive wording of PURPA regulations would help. In addition, the FERC should be encouraged to publish and make readily available a summary of the law's significant provisions and their implications. In particular, efforts should be made to insure that state regulators fully appreciate PURPA's value of service focus.

\section{Short Form License Applications for Existing Dams}

FERC's recently reduced licensing requirements for existing dam projects appears to be a valuable step in the right direction. Developments at existing dams with established impoundments are recognized' to cause substantially fewer environmental problems than new dam projects. In fact, the Wisconsin DNR indicated that long established impoundments represent a change in the state's ecological resources, which should be preserved. Moreover, the number of suitable hydro sites at existing dams indicates that reducing licensing problems for this class will greatly contribute to total hydro development.

Nevertheless, further improvements are desirable. The revised FERC procedure requires existing dam applicants to satisfy all state permitting requirements prior to filing for the federal license. None of the states studied engaged in any equivalent form of differentiation, in requirements or process, between existing and new dams. In fact, the DNRs in two of those studies, Michigan and Pennsylvania, expressed doubts that any such differentiation was appropriate. Thus, in states which have an active independent role in reviewing FERC eligible projects, the benefits of the federal distinction will be largely attenuated. Legislatures can correct this problem by creating distinctions comparable to the FERC breakdown. Additionally, legislatures should consider additional measures to further streamline the review of existing dam applications. 
V. MINOR OBSTACLES AND INCENTIVES TO HYDROELECTRIC DEVELOPMENT AND RECOMMENDED ACTION

A. Minor Obstacles

1. General Undervaluation of Hydroelectric Power by Government Decision Makers

All of the cases evidenced a tendency by regulators to underestimate the true value of hydroelectric generation, both in general, and at specific sites. For example, Wisconsin, Pennsylvania and Michigan DNR representatives questioned whether hydroelectric power offered a sufficient contribution to the power needs of their states to warrant any environmental dislocations. This concern was echoed by Wisconsin and Pennsylvania PUC staffs, and all of the energy offices except Maine. The Michigan DNR and the Maine PUC applied similar reasoning in justifying their opposition or failure to support the projects studied in those states.

At the general level, under valuation of hydro power can contribute to a failure to appropriately balance hydro development priorities against other state interests. At specific sites, this tendency can make permitting more difficult, add non-cost effective permitting conditions and even result in project rejections. Legislators, regulators and other decision makers should be encouraged to consider the value of hydro power in terms of its total contributions to state needs. Thus, the fuel replacement and pollution reduction made possible by hydro generation should be fully appreciated. As mentioned earlier, the new Maine hydro licensing legislation reflects an appropriate first step in this direction. Moreover, hydropower should be evaluated in terms of its incremental value, rather than according to its fractional contribution to total energy needs.

\section{2.: Wheeling}

-A small utility or cooperative developing a hydro site may find it necessary to transinit or wheel the power from that site to the area where it is to be used. These developers frequently must negotiate with a large investor-owned utility to obtain the needed transmission services. For example, the electric cooperative developer in the 
Pennsylvania case study has no distribution facilities near its proposed hydroelectric site and hence will need to have power from the site wheeled over the lines of a large investor-owned utility. PURPA includes provisions purporting to enable utilities to petition the FERC to compel a wheeling order. The FERC will review rates upon demand, or in the course of its wholesale rate regulation.

- The current system contains at least two impediments for hydro developers. The PURPA wheeling language contains a number of exceptions and qualifications which could be used to deny a wheeling request. Additionally, the FERC's current rate of return regulation approach does not appear to provide an effective check against a utility's monopoly pricing of its transmission services. The FERC does not question any wheeling rate which comports with utility industry conventions. This gives rate latitudes to utilities which may block wheeling from hydro sites. The Pennsylvania case provides a good illustration of this. The rates proposed by the wheeling utility, while consistent with utility industry standards, appeared to be substantially in excess of traditional rate of return regulation guidelines and approached what could be termed a monopoly rent. The rates were also substantial enough to discourage development of the project.

To improve this situation, wheeling order regulations should be limited to clearly warranted exceptions, such as a reduction in system reliability. Wheeling rates should be exposed to a FERC review to insure that rates are closely linked to the actual costs of providing the service. This will require the use of cost studies which reveal a utility's annual revenue requirements per $\mathrm{kW}$ of transmission capacity, adjusted for the customer's utilization of the system capacity; alternatively the annual revenue requirements per mile of capacity by $\mathrm{kW}$ class, adjusted for the wheeling customer's mileage could be used. In either case, the average or marginal energy losses attributable to the service, if any, should be accurately determined. Legislatures can help insure that FERC has the information and inclination to achieve a more accurate apportioning of wheeling costs among various transmission system users. 


\section{Recreational Requirements}

Federal recreation facility and reporting requirements place an additonal continuing drain on developer resources. The Wisconsin developer took particular note of the burdensome nature of these requirements and questioned their efficiency. The Michigan DNR, which has been absorbing most of the burden of federal recreational requirements for developers, has decided that it cannot afford to continue this service. Legislatures might want to reconsider whether the burdens created by these requirements are compatible with current energy and other public policy objectives.

\section{Fuel Adjustment Clauses}

The Maine study indicated that a PUC's interpretation of a fuel adjustment clause may dampen a utility's willingness to purchase power from a small facility. The Maine PUC determined that it would not permit Central Maine Power Company (CMP) to pass the cost of power purchased under a long term contract with the small hydro facility through the fuel adjustment clause, even though it had previously allowed comparable purchases to be passed through. This interpretation prompted CMP to break off its amicable contract negotiations with the developer, which in turn threatened project financing.

An interpretation which prevents the cost of power purchased from small hydro projects from being passed through a fuel adjustment clause inhibits voluntary power contracts between utilities and hydro developers. This interpretation also adds little, if anything, to rate payer protection, and is inconsistent with the principles of PURPA. Legislatures should revise fuel clauses to clearly authorize the pass through of small hydro purchase costs.

\section{Feasibility Analysis}

$\because$ The feasibility analysis is one of the most critical phase's of a hydro project. This analysis could incorporate all factors which have a potential bearing on the probability of bringing the project on line. Consulting engineering firms currently do a thorough job assessing hydrological and engineering factors, but tend to overlook or underestimate 
legal, financial, environmental, and institutional problems. Inexperienced developers may not know what they are missing. This result occurred in Michigan and Pennsylvania. In both cases, the feasibility studies accorded a treatment of legal and institutional factors that belied their significance or their implications for development. In such cases, the developers may receive a misleading impression about how difficult the development will be.

State legislatures should consider drafting guidelines on the minimum content of feasibility studies. This would inform developers about the information that should be received, and inform consulting firms about what should be provided.

\section{B. Minor Incentives}

\section{Early contact with Environmeintal Groups}

Nearly all hydroelectric projects have the potential for raising environmental issues, which may increase licensing delays or result in limitations on the operation of the facility. Most of the developers in the cases studied did not engage in any early communications with potentially interested environmental groups. In particular, the Michigan and Pennsylvania developers did not feel the need for any initial contacts with any environmental groups. This was partly attributable to fears that early involvement of environmental groups could prematurely kill projects in their highly vulnerable planning infancy and doubts that early contart would serve any useful purposes.

Avoiding early contact is trequently an unfortunate oversight. Contacting environmental groups during the early stages of a project can expose areas of probable concern, supplement the developer's environmental information, further an accurate assessment of project feasibility and defuse much potential opposition. The Wisconsin study offers some confirmation of this. Much of the smoothness and absence of delay in the processing of the utility's state and federal hydro licensing applications is attributable to the developing utilities' history of environmental concern and its aggressive consideration of the project's environmental implications from the inception of planning. Some environmental groups may even prove to be valuable developer allies. 
Developers should be encouraged to communicate with environmental groups while gathering information about project feasibility.

\section{Peaking-River System Management}

Peaking use of hydro facilities enables the optimum savings in fuel and pollution. It also causes the most environmental problems. The Wisconsin study revealed a river management approach which might provide a good compromise between environmental and energy goals. Water level fluctuations, and hence environmental damage, are confined to a few large reservoirs; discharges are utilized at multiple points along the river system. The phenomenon is not new, but coordination in planning the capacity and in operating the system can yield substantial energy gains. Incentives should be devised to encourage this cooperative approach.

\section{Energy Employment Acts}

The Michigan Energy Employment Act stimulates municipal development of hydroelectric power by authorizing counties and municipalities to cooperatively develop electric generation and distribution systems. The joint ventures and joint agencies formed by these public bodies can achieve substantial economies of scale in financing, constructing, licensing, and operating hydro facilities. It also enhances their bargaining position in negotiations with large utilities for power exchanges, reserves, wheeling and sales. The Michigan statute should serve as a model for analogous legislation in other states.

\section{Early State Review}

A number of the DNRs consulted expressed a preference for being informed about the project during the feasibility examination. The Michigan and Wisconsin DNRs were particularly interested in early review. In fact, Michigan has apparently succeeded in exposing PRDAs and federal licensing and feasibility loans to state A-95 review. Early preliminary review by state DNRs may enable developers to gain valuable information, anticipate state objections, and.respond to criticisms before becoming irretrievably committed to a particular development plar. This review can also be abused by hostile 
DNRs to discourage uninformed developers at the threshold level. Early review has merits which warrant its adoption, but its vulnerability to abuse would require that its effects be closely monitored.

\section{State Energy Offices}

The energy offices in most of the states manifested little commitment of resources or personnel to hydro development. The Minae and Georgia offices exhibited the greatest interest in hydroelectric development. Both have staff assigned to deal specifically with hydroelectric development problems. Some of the other offices, notably Wisconsin, appeared uninformed about fairly crucial topics of interest to potential hydro developers, such as sources of funding; the general thrust (or even the existence) of PURPA or FERC licensing changes. State energy offices should be directed to meet the needs of this energy resource and compliment other government efforts to stimulate its development. At a minimum, energy offices should make hydro licensing, development and financing information readily available. 


\section{INTRODUCTION}

This Executive Summary has been written to assist state legislators, their staffs and interested parties with a clear understanding of the findings of an in-depth technical study in a short and useful manner. This Executive Summary abbreviates for wide distribution the findings of two case studies of small-scale hydroelectric power at existing -- already constructed -- sites or dams. The full length case studies are available upon request from the National Conference of State Legislatures.

The use of hydraulic power to do useful work is an ancient practice. Similarly, societies have found a large number of reasons to alter or harness the natural courses of streams and rivers for such varied purposes as irrigation, water supply, flood control, recreation and electricity generation. In recent years the use of large scale dams for the generation of electricity has defined hydropower in the public mind. These projects. -- Hoover Dam, Grand Coulee Dam, the work of the Tennessee Valley Authority -- have . made enormous contributions to the growth and industrial power of the United States, but large scale technological projects are not entirely without environmental or social costs. Nevertheless, hydropower remains a popular and reliable source of baseload electrical energy.

In order to provide for growth in the demand for electric energy, hydropower may be able to provide an alternative to thermal generation -- coal or nuclear -- in certain locations around the country. Adapting small existing sites or dams for hydroelectric generation can be a more efficient or complete use of a hydraulic resource, and the environmental and social impacts of large-scale hydropower or thermal electric generation may be avoided.

In part, the development of small-scale hydroelectric power is a reflection of a new consciousness developing in the United States about electricity: because of the rising economic and social costs of new generating capacity, existing energy resources have to be used more completely in planning for future demand. These case studies 
outline the progress of two very different developers adapting existing sites for the generation of hydroelectricity -- at the South Columbia Basin Irrigation District and the City of Portland's Bull Run Water Reserve -- with attention toward identifying the incentives and impediments to this kind of activity. Although many of the details of each case are site-specific, state legislators and their staffs may be able to use these documents by comparison to examine the general incentives and impediments which may exist at sites in their own states.

The University of Washington's Program in Social Management of Technology (SMT) is a problem-oriented interdisciplinary research and teaching unit affiliated with the College of Engineering which examines technology-intensive public policy issues. In addition to engineering and the physical sciences, SMT draws on economics, political science, law, business and public administration in working with the public policymaking process.

SMT's Small-Scale Hydropower Project, formed for the purpose of this study, consisted primarily of two faculty members and two graduate students:

Larry Schwartz, Principal Investigator and Faculty Research Associate

John G. Douglass, Faculty Research Associate

Jeffrey James, Graduate Rescarch Assistant

Larry A. Meyer, Graduate Research Assistant

Mr. Schwartz, a specialist in energy policy and its impacts, and Mr. Douglass, a specialist in energy technologies, may be contacted directly for any questions or comments regarding this study at the Program in Social Management of technology, University of Washington, Seattle, Washington 9819.5. The telephone number is (206) 543-7029.

\section{SUMMARY}

This section outlines the key incentives and impediments to small-scale hydropower development identified in case studies of the South Columbia Basin 
Irrigation District and the City of Portland's Bull Run Water Reserve. These are presented, together with the conclusions and recommendations of the study team concerning their consequences for future small hydropower developments.

The Sites and Their Developers

The small hydroelectric power projects reviewed in these case studies are:

-- Six sites in the irrigation system known as the Columbia Basin Project, the lead organization being the South Columbia Irrigation District, Pasco, Washington.

- Russell Smith, Secretary-Manager.

-- Two sites in the Bull Run watershed which supplies water to the City of Portland, Oregon. The developer is the Bureau of Water Works of the City of Portland, Oregon. Francine J. Ivancie, Commissioner of Public Utilities, Jim Doane, Manager, Hydropower Development.

Impediments, Conclusions and Recommendations

* Developers at both case study sites reported in interviews that the costs and delays imposed by dealing with the federal government and its licensing process are considerably greater than those imposed by their respective states. When asked about the single greatest impediment to small hydropower developments at the South Columbia Basin Irrigation District, its Secretary-Manager Russell Smith stated, "Our largest regulatory problem has been, and is expected to be, with FERC.... The (Washington) State process has been relatively easy, and state organizations have been cooperative..." (in interview, 21 May 1979). In addition to the costs and delays imposed by the FERC licensing process, the South District was forced to wait over a year and a half (August 1977 to April 1979) for approval from the Secretary of Interior for their project under the terms of their repayment contract with the Bureau of Reclamation -a contract which acknowledged the possibility of such development.

At the Bull Run Site in Portland, Jim Doane, the manager of the hydropower project told a similar story in his interview with the study team. The greatest amount of time and money was spent fulfilling the requirements for the FERC licence application. The 
application was more than sufficient for the State of Oregon's licensing and permitting process.

At Bull Run, the overlapping of City, State and federal jurisdictions in the. Bull Run watershed area was an additional serious complication in the project's development. As a result of a Presidential proclamation and turn-of-the-century federal legislation, the Water Bureau was not permitted to enter the Bull Run watershed for purposes of hydropower development planning, by ruling of a U.S. Circuit Court Judge. Resolution of the problem took an Act of Congress as well as serious delays and additional costs.

The U.S. Internal Revenue Service has adopted curious codes concerning the local furnishing and consumption of electricty. The administratively mandated "two-county" rule requires that when municipalities sell power to private utilities, the latter must guarantee that all of the power produced be consumed within two counties or the revenue bonds financing the project become taxable, raising the cost of the entire project. Although it is technically impossible to "trace" electricity, Portland General Electric will be required to take unusual measures at additional cost to guarantee that all of the Bull Run power is consumed in two counties. Congress and the IRS should review the wisdom of this kind of rule, given the interconnected nature of the electricity system in the United States.

From these examples, it seems evident that not only the FERC regulatory process, but the entire federal legislative and regulatory impact on small hydroelectric developments in the states should be reviewed.

*In some states, codes governing the organization of irrigation districts have the potential of creating large obstacles for small hydropower developments. In the case of the Columbia Basin Project, existing State codes permitted irrigation districts to borrow money for a maximum of 10 years. The State Legislature, during its 1979 biennial session agreed to raise the time limit so that long-term bonds could be sold -permitting the District to raise necessary construction capital. These kinds of arbitrary limits are an obstacle to small hydropower which should be reviewed in all states. 
*In some states, the state department concerned with fish and wildlife may be able to slow or stifle small hydropower developments by demanding restitution from potential developers for damage incurred during the original construction of the site.

In Portland, 'the Oregon State Department of Fish and Wildlife was successfully able to intervene in the licensing process for the Bull Run hydropower projects until the Water Bureau agreed to make payments for a migratory fish run which was unwittingly destroyed during the construction of Dam No. $\mathrm{L}$ in 1929. Although the city of Portland was able to accomodate this requirement, such demands by Fish and Game could successfully prevent a small hydropower developer from converting an old site constructed by others. The problem of balancing environmental and energy requirements deserves special attention from the responsible parties -- mandatory intervention by fish and wildlife departments may raise significant obstacles to hydropower.

Incentives, Conclusions and Recommendations:

*The ability of the developers to find ready purchasers for their power using innovative economic arrangements was important in making the small hydropower sites economically attractive to both parties.

Developers in both case studies employed "share-the-benefits" power purchase ․ agreements, requiring the utilities to pay higher prices for electricity in the early years of the agreement, but sharing in the savings as the costs of other sources of power rise.

In Seattle and Tacoma, the Columbia Basin Project found a "partnership" for development, obtaining essential front-end financing for costly engineering studies so that licensing and permitting activities could begin prior to the sale of bonds for construction financing. Benefits will be shared when the average cost of utility power from other power plants rises above the cost of power from the site.

Portland sought the best price it could obtain for its power, relying on itself for developing the sites. Benefits will be shared with Portland General Electric when the cost of power from the utility's most recently constructed 500 megawatt or greater 
thermal base load generating facility rises above the costs of power from the sites.

* The work of farsighted planners during system/dam construction added considerably to the feasibility of developing hydropower at Bull Run today.

When Dam No. 1 was completed in 1919 and Dam No. 2 was completed in 1962, each was equipped with the penstocks for the development of small hydropower. Although the planners of each dam knew at the time that the sites were not economically feasible, they could envision a day when such development would be a logical step. Consequently, the costs of constructing the hydroelectric facilities will today be less than had the penstocks not been included during original planning and construction.

\section{SASE STUDIES}

\section{A. South Columbia Basin Irrigation District, Pasco, WA.}

The Columbia River and its basin have long been associated with the power of nature and of man. It is believed that about $1 / 3$ of the hydroelectric energy potential in the United States is in the Columbia River and its natural tributaries -- few other rivers in the world carry as much water quite so precipitously.

This case study is concerned with two modern "uses" of the Columbia River -- irrigation aimed at agricultural land reclamation and hydroelectric power. Both of these uses are the result of enormous engineering feats -- natural and human. The Columbia River carved out the Grand Coulee -- a valley fifty miles long, two miles wide and two thousand feet deep -- in the last ice age about 10,000 years ago; the United States has built the Grand Coulee Dam and the Columbia Basin Project over the last half century.

The Grand Coulee Dam has become synonymous with large-scale generation of hydroelectric power, providing the Pacific Northwest with some of the least expensive electricity in the United States. The Columbia Basin Project has created a halfmillion acres of farmland in the State of Washington out of a spectacular and vast desert. 
The South Columbia Basin Irrigation District is planning for the development of small-scale hydroelectric power at the Columbia Basin Project and is expected to begin construction in 1980 on the first of several sites planned for development. In the present era of tight capital, looming energy shortages, public skepticism about costly and large-scale technologies endeavors and the widely perceived need to preserve, rather than conquer Nature, the South Columbia Basin Irrigation District is seeking to harness the energy present in the water which already runs through its canals, drains and wasteways. As a nonprofit organization, the South District's strategy in developing the small hydropower sites is aimed toward reducing the costs its farmers pay for the irrigation system and raising the capital requred to save the remaining 550,000 acres originally planned as part of the Columbia Basin Project.

The Small Hydropower Sites

At present, six sites in the Columbia Basin Project are being planned for hydroelectric power development. Together they represent a total of about 100 megawatts of energy. They are referred to in this study and on the map as: Dry Falls, Summer Falls, Potholes East Canal Headworks, P.E.C. 22.7 Eltopia Branch Canal (E.B.C.) 46 and P.E.C. 66. The Dry Falls Dam site at Banks Lake is where the entire system flow takes a large elevation drop into Billy Clapp Lake. The P.E.C. (Potholes East Canal) Headworks site is the outlet to Potholes Reservoir at O'Sullivan Dam. P.F.C. 22.7 is a check structure 22.7 miles downstream form the Headworks where the canal elevation is lowered to accommodate a drop in terrain elevation. E.B.C. (Eltopia Branch Canal) 4.6 is a chute which accomodates a drop in terrain elevation 4.6 miles downstream from the headworks where water collected from a high irrigated area drops 304 feet into the Columbia River.

The South District has marketed the power to be generated by the sites as a package. Due to the seasonal flow of water through the irrigation canals, the power will be available only from about March 15 to October 31 of each year. The site known as P.E.C. 22.7 will receive the greatest attention in this analysis. The developers 
decided to use P.E.C. 22.7 on a pilot project. In this manner, any unforeseen problems or contingencies could be identified early and appropriate planning and scheduling decisions could be made.

History/Background of Small Hydropower Development

Russell Smith, the Secretary-Manager of the South Columbia Basin Irrigation District, was aware for many years that the irrigation districts held title to potentially feasible hydroelectric power sites, not only because of his current work with the District, but also from his many previous years as an employee of the Bureau of Reclamation. However, along with his colleagues and the Directors of the districts, Smith was unconvinced that the "time was right" for developing them.

In 1975 the Tudor Engineering Company began to study the potential and feasibility of small-scale hydroelectric power with its own funds. After identifying several sites in the Columbia Basin Project, Harry Hosey of Tudor contacted Russell Smith at his offices in Pasco, Washington. Smith remained unconvinced that the sites in the irrigation district were economically feasible, that the Project could obtain the necessary permission from the Secretary of the Interior, that the necessary funds could be raised, and that a suitable power purchase agreement could be obtained.

In early 1977, after periodic encouragement from the Tudor Engineering Company, Smith agreed that the time was right for development and sought formal permission trom the South District's Board of Directors to begin work on the project. In late summer 1977, Smith sought permission of the Reserved Works Committee to take a lead role in developing the sites which were not exclusively in the South District's territory and were therefore under the Committee's authority. Although the members of the Committee were pessimistic about Smith's ability to obtain the requied permission of the Secretary of the Interior and to obtain workable financing for the hydroelectric projects, they delegated authority to the South District to pursue such actions for the time being.

In retrospect, Russell Smith acknowledges the instrumental role of the Tudor 
Engineering Company in convincing himself and his superiors of the need for and marketability of the energy available from water in the Project. Tudor was rewarded for its persistence by becoming the prime contractor for the small hydroelecrric development projects.

Tudor and Smith decided that in order to ease the entire project through its legal, regulatory and environmental requirements that one site, P.E.C. 22.7 , which seemed a prototype for the project and which was entirely under the jurisdiction of the South District would be advanced first, with the others to follow shortly thereafter. In this manner, any unforeseen problems or contingencies could be identified early and appropriate planning and scheduling decisions could be made. In August 1977 the Columbia Basin Project sent a letter to the Secretary of the Interior formally requesting permission to develop a hydroelectric facility at P.E.C. 22.7.

While awaiting approval from the Secretary, Smith and Tudor proceeded with a preliminary application to the Federal Energy Regulatory Commission (FERC) in order to reserve the site at P.E.C. 22.7. The preliminary FERC application was submitted in Februrary of 1978. Then Smith and Tudor began work on applying for the appropriate Washington State licenses and permits, since the permission of the State is a key factor -in FERC's decision to grant licenses for power production.

The District was aware that as a nonprofit organization with limited funds and legal restrictions on their ability to raise money through the sales of bonds, they needed more than simply a customer for the power that they would ultimately produce. In order to obtain the needed capital for engineering plans, the permit and license processes and construction, the irrigation districts needed a financial partner.

In the spring of 1978 , the South District also began to identify prospective purchasers for the energy they would produce -- purchasers with sufficient capital to act as partners who could assist in the financing of the site development. The search was, to say the least, informal. After identifying about 26 prospective "partners," the South 
District began consultations with each, using the preliminary application to FERC as a project description. Before the call for bids, many of the prospective purchasers eliminated themselves due to special requirements.

Among those under consideration were several aluminum companies which were searching for sources of electricity to replace the Federal power they will be losing over the next few years. The Bonneville Power Administration (BPA), which markets the relatively inexpensive Federal power produced in the Pacific Northwest, has notified local manufacturers of the energy-intensive aluminum products that their power contracts will not be renewed as it attempts to accommodate the growing public utility market. However, due to the seasonal character of the power to be supplied by the project, the aluminum companies withdrew from consideration.

Other potential customers included several rural electrification administrations (REAs) and public utility districts (PUDs) all of whom required the storage of power by the BPA system. Since BPA could not promise to cooperate for the time being, these, too, were dropped from consideration.

When bids for the power were finally solicited in late 1978 most of the state licenses and permits had been obtained. Seattle City Light.and Tacoma City Light, who had submitted their bid cooperatively, were selected for further negotiations. The PUD of Grant County, Washington, was selected as standby, should no final agreement be reached with Seattle City Light and Tacoma City Light. The two cities offered to assist in development of the sites in addition to purchasing the power produced by the projects.

With the preliminary FERC licenses in hand as well as the appropriate State permits and licenses and prospective power purchasers and financial assistance, the remaining major obstacle was the formal FERC license application and the agreement of the Secretary of the Interior, whose permission had been sought in August of 1977. After what Smith describes as "a great deal of arm twisting" by the State of Washington's delegation to Congress, permission from the Secretary arrived in April, 1979. 
In the State law which organized irrigation districts, there were legal limitations on the length of time for which development bonds could be sold. The irrigation districts were limited to borrowing money using 10-year bonds, but in order to be able to raise the larger sums of money for hydroelectric development, they needed to borrow money for a period of 40 years. At the requests of the South District, the State Legislature amended the code during its 1979 legislative session not only to permit the selling of 40 year bonds but also specifically authorizing irrigation districts to develop hydroelectric generation capabilities in connection with irrigation facilities.

The South District has expressed its pleasure with the willingness of the State Legislature to cooperate in amending the codes to ease the way for small hydropower development at existing sites. However, the legislature's actions were entirely consistent with policy it had adopted during the previous session. Senate Bill 3170 stated in part:

The development and use of a diverse array of energy resources with emphasis on renewable energy resources shall be encouraged.

The application to FERC for a hydroelectric power generation license was submitted by the South District in June 1979. All agencies of the State of Washington were to comment to the Federal Energy Regulatory Commission (FERC) by September 1979, when this case study was being completed. Whether this project is to be completed on schedule depends largely on FERC's ability to rapidly process applications for small hydroelectric facilities at existing sites.

Construction is scheduled to commence at P.E.C. 22.7 in the summer of 1980 . Since work on the hydroelectric facility cannot interrupt the delivery of water to the region's farms, construction of the penstock and inlet will begin in the fall of 1980 . The powerhouse, tailrace and switchyard will follow, with generation commencing in May of 1981.

The Partnership for Development

Publicly owned utilities are a strong tradition in the Pacific Northwest. Both Tacoma and City Light and Seattle City Light were formed early in the Century. For 
many years, the Bonneville Power Administration (BPA), the regional marketing agent for Federally-generated power, has been meeting the full requirements of the public utilities above the resources they own themselves. But BPA has informed public utilities that its resources will not be sufficient to meet their growing needs after 1983.

When presented with the need to develop more of their own electric resources in earnest, and with most of the best hydroelectric sites apparently either taken or politically and environmentally untouchable, the public began to look toward thermal power plants -- principally nuclear-and coal-fueled -- to provide for their future additional electricity demand.

Because Seattle and Tacoma own their electric utilities, the future sources of electricity are a matter of public concern and policy at the local level. Seattle City Light and Tacoma City Light as public entities must be responsible to the citizens, primarily through their elected representatives, the Mayor and the City Council.

In Seattle, the dilemma posed by BPA notice of insufficiency, together with substantial local opposition to thermal electric power plants, primarily nuclear power, led to a major city-wide study known as "Energy 1990." The study, which involved a broad range of citizens' groups, energy experts and public officials in addition to Seattle City Light led to a number of recommendations, many of which were mandated by City Council or implemented by the utility directly.

On July 12, 1976, the Seattle City Council adopted Resolution 25260 -- one which was a direct outgrowth of the "Energy 1990" study -- as a policy directive to the Lighting Department. It said, in part, that:

Hydropower shall be the preferred method of generating electricity so long as hydro resources remain that can be economically developed on an accept able environmental basis...

That policy directive, together with the knowledge that in 1985, the peak and average electrical demand of Seattle City Light and Tacoma City Light may begin to seriously outstrip their supplies of owned and available purchased energy, put both utilities in a position which was particularly favorable toward the acquisition of firm small-scale hydroelectric resources. 
Agreement for Power Purchase

In the Pacific Northwest, any hydropower produced at a cost equal to or below the BPA new resources cost index could probably find a public utility able to purchase power at the BPA preference customer rate, savings or "financial benefits" will begin to be realized from the purchase of energy from a new source such as P.E.C. 22.7 when that BPA rate exceeds the cost of that particular source's energy. However, the existence of many uncertainties regarding the availability and ultimate price of BPA power in the region adds to the economic attractiveness of almost any new firm hydropower resources, even at costs which are currently above market values.

In December 1978, the South Columbia Basin Irrigation District's search for "partnership" came to an end as it agreed to negotiate a "Memorandum of Understanding" with the cities of Seattle and Tacoma for the purchase of power from P.E.C. 22.7. IJnder the terms of the accord, the Cities and the three Irrigation Districts will enter into formal agreements covering the power from the subsequent hydropower developments within the Columbia Basiri Pivjecl as long as the developments conform with agreed-upon cost criteria.

Although the exact terms of the agreement have not been legally finalized, interviews with the irrigation districts and with the power managers for both utilities confirm that:

-- The districts will construct, own and operate the project. They will obtain their own financing through tax-free revenue bonds (since they are nonprofit organizations and will be selling their power to public utilities).

-- Seattle and Tacoma will purchase the power output of the project for a period of 40 years, beginning the date of commercial operation. The utilities will obtain the necessary permits and licenses for power transmission and will make payments to the irrigation districts sufficient to cover the debt service on the bonds and the site's operations and maintenance costs. The utilities will also provide the irrigation districts with some funds required for development prior to the sales of the construction bonds.

-- The costs of the power to the cities will be the costs of producing the power plus a fixed "fee" for the District." After the average costs for the utilities reach the costs of producing the power at the site, the utilities and the ir rigation districts will equally share the difference between the average costs of power to the cities and the costs of power from the site. 
This is known as a "share the benefits" agreement of payment which is becoming increasingly popular among small hydro developers. Although in the earlier years of the agreement the utilities pay more for the electricity from the site than they pay for most of their resources, as costs rise in the future they will be saving money -perhaps substantial sums, depending on how much those costs escalate -- from the energy produced at P.E.C. 22.7.

In 1978, the estimates for the cost to the District for producing electrical energy at the lineside terminal of the switchyard transformer at P.E.C. 22.7 was about 13 mills/kwh if the project was financed with tax-exempt bonds totaling $\$ 3.65$ million. Under the present agreement, Seattle and Tacoma will be paying the Districts a total of about 15 mills/kwh amounting to a "profit" or "Entrepreneurial fee" of about 1.65 mills/kwh for power produced at P.F.C. 27.7. These monies must all be expended in a given year, since the Districts are nonprofit, tax-exempt, organizations.

The benefits to the utilities begin to accrue further into the future. As the BPA preference customer rate and the cost of new electrical resources rise over the next several years, the average costs of power from all sources to the utilities will begin to rise. When the average costs become greater than the cost-plus-fixed-fee rate Seattle and Tacoma are paying the District, the utilities will be permitted to keep half the difference br tween the fees and the average costs. As their average costs continue to rlse over lille, the utilities will come to viow the electricity from P.E.C. 22.7 as. increasingly inexpensive.

Lessons of the Case Study

The development of six small hydroelectric generation facilities totaling 100 megawatts at the South Columbia Basin Irrigation District will stretch out over the next decade. The first site, P.E.C. 22.7, is proceeding on schedule and is expecting to begin generating electricity in 1981.

Those of us participating in this case study found considerably fewer Stateimposed regulatory and economic barriers than we had expected; all key actors in the 
project singled out federal regulatory requirements and the costs (and delays) they impose as being the most significant barriers to the development of small-scale hydroelectric power. However, in both of the case studies, state and federal processes, legislation and regulations created site-specific, unintended constraints or deadlocks in the developers' schedules. Because of the overwhelming public approval for hydroelectric generation in the Pacific Northwest, everyone in federal and state agencies seemed genuinely anxious to assist with the first new small hydroelectric project at an existing site in the State of Washington.

In an attempt to summarize what we have learned about small-scale hydroelectric power and its future, the study team is presenting its observations, conclusions and recommendations below.

* The water running through the Nation's gravity based irrigation districts represents 'a large and potentially useful hydroelectric resource. Since the early days of the Columbia Basin Project, land reclamation through irrigation has been closely associated with the generation of hydroelectricity. Although the study team found no credible conjecture of the potential electric capacity available to the Nation from the exploitation of hydropower in all such districts, it is known that an average of 156 billion gallons of water are used per day for U.S. irrigation. Because they are existing sites with regularly monitored and controlled flow rates, irrigation structures may be the best possible sites for small hydroelectric generation with a minimum of unintended consequences or impacts.

* The State of Washington should amend and simplify its regulatory process to facilitate the licensing of small-scale hydroelectric facilities at existing sites. Although P.E.C. 22.7 won easy approval from the State, it is easy to see that the regulatory process for hydroelectric facilities remains cumbersome at best. This is understandable, because 
Washington State is accustomed to dealing with large-scale hydroelectric facilities with their large-scale impacts.

Although the Department of Ecology holds much of the responsibility for hydroelectric facility licensing and inspections, other departments and agencies have a role in the process. It is the finding of the study team that the adoption of a "one-stop" licensing and permitting process for small hydroelectric developments at existing sites in Washington State would be useful. Of greatest use, however, would be the adoption of procedures and requirements commensurate with the scale of the proposed project -ones. which simplify paperwork for both the developers and the State and which speed the licensing process while protecting the environment and public safety. In passing the State environmental Policy Coordination Act (State EPCA) the Washington State Legislature demonstrated an interest in expediting the environmental review process by requiring the Department of Ecology to assist a developer in the rapid identification and processing all required State licenses and permits when a master application form is submitted. In the case of P. E.C. 22.7 the developers did not choose to file under State EPCA, since they were relatively familiar with the State regulatory processes. However, the law may be used to provide developers who are unfamiliar with the process a comprehensive enumeration of the regulatory requirements which must be satisfied before a project may begin .

The slate of Washington's hydroelertrir farility regulatory process was largely designed to protect the interests of the public in the licensing of large-scale hydroelectric facilities. Recognizing this fact, the Department of Ecology has independently begun licensing procedures to speed the applications for small hydro facilities at existing sites. We believe these are positive steps, but that the State Legislature should at least give firm . policy direction to the Department of Ecology specifically stating its desire to simplify small hydroẹlectric facility licensing.

In interviewing the developers, it did not seem that the fees charged by the State for the hydropower production license and its annual renewal will be prohibitively large. 
At this writing, the question of whether the South District must pay such a fee is before the State Attorney General. It is our belief that such a fee in excess of the costs to the State for seeing the public's interests protected is at best unnecessary for small hydroelectric facilities -- at worst it may pose a costly obstacle. The State Legislature may wish to reevaluate the fees and consider eliminating them for certain small hydroelectric facilities.

* The extraordinary efforts of individuals (entrepreneurial company; activist secretary = manager of the South District) within established organizations have been instrumental in planning for the development of small-scale hydropower at existing irrigation district facilities in the Columbia Basin Project. Recently signs have emerged indicating that small-scale generation of hydroelectricity is a source of potential future electric capacity worth exploiting Notable recognition of this potential by the federal government came with the National Energy Plan proposed by President Carter in April 1977 and with FERC's announced plans to adopt regulations to ease small hydro lịcensing.

Russell Smith, the secretary-manager of the South Columbia Basin Irrigation District, has been involved in the growth and development of the Columbia Basin Project for much of his professional career -- with the U.S. Bureau of Reclamation with contractors building the Project and later with the South District when it was formally organized. Smith recounts that the energy implicit in the Columbia Basin Project was recognized throughout its history, but that its effective exploitation had to await economic feasibility. It was 1975 when Harry Hosey of the Tudor Engineering Company's Seattle office first, approached Smith with the suggestion that small hydroelectric sites be developed at the Columbia Basin Project. The Tudor Engineering company was sufficiently convinced of the economic feasibility fo small hydro that it was willing to do preliminary studies of P.E.C. 22.7 with its own money just to prove feasibility to the irrigation districts. Once convinced that such an undertaking would be both useful and in the District's interest, Smith began to actively support and 
aggressively pursue the development of small hydropower for the entire Columbia Basin Project under the auspices of the South District, managing the entire effort himself.

Developing a small hydroelectric facility remains no simple undertaking, even though many people are sufficiently skilled in the area. It is our belief that, especially in the near term, there will be no headlong rush among small groups or businesses to develop new hydropower facilities, even if such federal programs as President Carter's Rural Energy Inititatives of 1979 succeed in encouraging their development at existing sites. In the near term the most successful developers of small hydropower will be those well organized groups, companies, and utilities already somewhat familiar with hydroelectric development and who can, or must, accept the high financial risks for a period of time in order to accept benefits spread out over the longer term.

* An unusual power purchase agreement was important in making the small hydropower sites economically attractive to both the irrigation districts and the city utilities. "Share the benefits" purchasing agreements are rapidly becoming a key feature in the economic feasibility of many small-scale hydropower developments around the country. Although they may not seem so to those less familiar with electric utiliţies, such purchase agreements are a radical departure from past practices.

Historically, utilities have preferred to generate their own electricity, purchase it from federal generation stations or cooperatively generate it with other utilities. In the event that power had to be purchased, utilities have preferred to buy it from each other. This business practice has had the effect of guaranteeing the monopoly of electric utility companies, both public and privately owned, over the production and sales of electric power.

The Public Utilities Regulatory Policies Act (PURPA), one of several pieces of federal legislation emerging from President Carter's National Energy Plan, was an important factor changing this practice. It requres utilities to purchase electricity from all potential suppliers at a fair price. Also, as public utilities, Seattle City Light 
and Tacoma City Light are under the jurisdictions of their respective city councils. Consequently, they have proven themselves less inclined to pass up future energy resources which are politically popular for an outdated business practice/principle, i.e., that utilities must own all non-federal electrical generation capacity.

By adopting a "partnership" arrangement with the South Columbia Basin Irrigation District, Seattle City Light and Tacoma City Light have agreed to provide valuable "front-end" financing and higher-than-average prices for power in the earlier years of their 40-year arrangement in exchange for what may turn out to be considerable savings in the more distant future. For many potential small hydropower developers, the availability of early financial support is extremely important -- perhaps critical -- in guaranteeing that the costly engineering studies, licensing and permitting activities may begin prior to the sale of bonds which finance construction.

* The use of one lead site, P.E.C. 22.7, among the six under consideration for small hydropower development was a useful planning strategy for the identification of and preparation for legal and institutional obstacles at the state and federal levels.

Simply put, there is a "learning curve" associated with small hydropower developments in a given State -- both for the developers and for the various licensing/permitting institutions.

Although there have been no major obstacles to date, the developers indicate that they learned enough during the licensing and permitting phases completed to date that the preparation of key applications for the other sites will be speeded.

However, institutional learning has made much greater strides in the state and federal governments as a result of the "lead site" strategy. As a result of groping with how rigorously they must scrutinize P.E.C. 22.7, the Department of Ecology is making steps toward simplifying their oversight for all small hydroelectric power developments at existing sites. Even more dramatic was the progress made with the Secretary of Interior's approval process. Although it took from August 1977 to April 1979 for the 
South District to obtain the contractually required approval from the Secretary for the development of hydropower at P.E.C. 22.7 -- approval which was obtained only after approaching the State of Washington's congressional delegation for assistance -- they received the OK for the Dry Falls site in a matter of only three months.

In the submission of applicaitons for one lead site, the developers avoided the much greater risks which they would have had to face by doing all of the background studies and applications for all six sites -- then waiting uncertainly while state and federal regulatory authorities pondered permission to go ahead with all six.

* The proposed developments enjoy support from state institutions and the press. No negative comments have been received from environmental groups or neighboring towns and counties. I his may be the basis for cautious optimism concerning similar projects for the future. Because of the enormous popularity which hydroelectricity and renewable energy technologies enjoy in the State, there has been no identifiable oppositon to these proposed small-scale hydropower projects. In fact, the developers have found the State Legislature, the Department of Ecology, the press and almost anyone. who has come in contact with the project to be highly supportive of their efforts. Although this is moderately encouraging, the utmost caution should be used in extrapolating such support to small hydropower projects at existing sites which might be located on natural, as opposed to man-made, waterways.

*Hydropower development at the Columbia Basin Project is partly a strategy for growth. The irrigation districts hope to expand in order to serve the additional $1 / 2$ million acres they were originally planned to serve under contract with the Bureau of Reclamation.

* Widespread adoption of small-scale hydropower systems by irrigation districts around the country may become a variable in the current federal reappraisal of water projects. 
The Columbia Basin Project currently serves over $1 / 2$ million acres of farmland in central Washington and has been planned to serve another $1 / 2$ million acres. In recent years, the pace of work toward completion has slowed considerably. The federal government has entered a period when funds for water projects are considerably more restricted than in the 1930 s when the Columbia Basin Project was planned. This may be due to economic studies and political criticism of such projects suggesting that they represent subsidies to farmers in one state from the taxpayers in other states and that the key criteria in funding decisions have become political "pork barreling" rather than in the national interest.

Caught up in the controversy, the Bureau of Reclamation has been seeking, in recent years, to raise the farmers' rate of payment (also known as repayment) for irrigated acreage. Not surprisingly, the farmers, through the irrigation districts, have resisted such pressures. In sum, then, the farmers want to see the irrigation district completed and their payments for water deliveries kept low while the federal government is putting less money into irrigation projects and trying to raise the price of water deliveries for both present and future irrigated acreage.

Without either taking sides or going into great detail about this controversy, the introduction of hydropower generation by the irrigation districts may have unintended implications for both of the key factors. For example, the revenues available to the irrigation districts as a result of power sales could undermine its argument that the farmers are unable to pay higher prices for irrigated acreage or generally assume more of the costs for the Project's expansion. On the other hand, the availability of hydropower from sites in easily licensed and constructed irrigation systems may be considered sufficiently important for the Nation that the federal government will be willing to step up expansion of the Columbia Basin Project in order to increase the area's electrical capacity.

It remains to be seen whether unintended social, environmental or economic consequences -- either positive or negative -- will arise from the exploitation of the 
Nation's small hydropower sites, since little attention is currently being devoted to these possible consequences.

\section{B. Bull Run Hydroelectric Project, Portland, OR}

The City of Portland, Oregon, is located on the Willamette River in nor thwestern Oregon at the western edge of the Cascade mountain range. It was incorporated in 1851 and named after Portland, Maine, the hometown of one of its founders. Until 1895 the city's water supply came from local wells, creeks and the Willamette River. As the area grew in population many nearby sources of water became polluted, and local residents began searching for future sources of pure drinking water supplies.

Portland réceives quite a bit of rain each year from moisture-laden Pacific winds. Each winter, large amounts of water are stored as snow in the Cascade mountains to the west of the city, which results in many fast-flowing streams and clear mountain lakes. It was natural that the residents of Portland should look toward these sources of fresh water to supply the city's future needs. In 1888, Bull Run Lake and the Bull Run River were selected as the most preferable future water source for the city; on January 1 , 1895, Bull Run water traveled the 35 miles to enter Portland for the first time.

This case study examines the small-scale hydroelectric project under development at the city of Portland's water reserve in the Bull Run Forest Reserve. Foresighted planners reçognized that the water works might be useful sources of hydropower when they were constructed, so the two water storage dams at the watershed were equipped with penstocks when they were built. Portland had only to wait until the need for electricity made the sites economically feasible and its water supply system could also become a small hydroelectric power station.

Under the supervision of the Portland Bureau of Water Works, construction is currently underway on the project and is proceeding on schedule. The Bureau plans to begin power generation on January 1, 1982, selling the average 100 million kilowatts of power to Portland General Electric Company (PGE), a private utility which serves about 3,350 square miles of northwestern Oregon including Salem and about half of Portland. 
Given the serious electricity shortages forecast for the Pacific Northwest in the 1980s, this case study demonstrates that small hydropower generation at existing sites such as water storage dams can make a contribution to the area's resource availability through the more complete utilization of structures also used to store drinking water.

The particular concerns of this case study are the economic, institutional, political and regulatory problems of harnessing the energy at the two Bull Run water storage dams in an attempt to offer legislators, their staffs and interested individuals the opportunity to consider the problems of small hydroelectric power developments at existing sites.

History and Description of the Site

The use of Bull Run Lake and the Bull Run river for Portland's water supply began when the Oregon State Legislatures passed an act in 1885 creating the Portland Water Committee and authorizing the construction and maintenance of a public water system. During 1886 the Committee put together a financial package enabling them to purchase the Portland Water Company which had served the City since 1862, supplying water from local creeks, wells and the Willamette River.

Although the committee also studied the possibility of obtaining water from Eagle Creek and the Clackamas River they decided that the Bull Run River was the most preferential future water source, a decision that was the object of much criticism at the time. Apart from the obvious cost involved in bringing water more than 35 miles over rugged countryside, it was believed that Bull Run water was glacial and therefore possibly unhealthy. The water in the Bull Run watershed is now known to be of very high quality and no filtration is required for domestic use. Portland's public officials like to boast that it is so pure and free of minerals that it can be put directly into automobile batteries without prior distillation.

A contract to construct the headworks was awarded on September 2, 1886, but all action was suspended until a $\$ 2.5$ million bond issue was authorized in 1891. In 1892, President Benjamin Harrison's proclamation set aside the Bull Run reserve to protect 
the city's water supply. Construction on the headworks and conduits began in 1891 and water from Bull Run entered the city of Portland through Conduit No. 1 for the first time on January $1,1895$.

Six reservoirs and three conduits supply Portland with water today; however, the need for further storage was recognized in the mid-1920s. From 1927 to 1929 a concrete gravity dam 200 feet high and approximately 900 feet long was built on the Bear Creek site, now known as Dam No. 1, which backed up Lake Ben Morrow. This provided a storage of 8.8 billion gallons. It was increased to 10 billion gallons in 1955 by installation of vertical lift gates which added 8 feet to the water level.

In the 1950s, postwar suburban growth greatly accelerated, and additional demand on the Bull Run water supply dangerously overtaxed the existing system. In 1959 the Bureau of Water Works went ahead with its plans to build Dam No. 2, an earth-filled structure only a short distance upstream from the headworks. The dam cost \$8 million and took three years to complete. Its construction was plagued by a major washout from a flash flood and a default by the contractors on the job. Finally completed in 1962, Dam No. 2 has an impoundment capacity of over 7 billion gallons.

In what today seems a display of excellent foresight on the part of Portland's water resource planners, both Dam No. 1 (1929) and Dam No. 2 (1962) were constructed with the penstocks required for hydropower development, the expectation being that one day such development would become economically attractive. That development is currently underway, with Dam No. 1 being equipped with a 24 megawatt generator and Dam No. 2 being equipped with a 12 megawatt generator.

As a safety precaution to protect the health of Portland's citizens in 1904, Congress passed the Bull Run Trespass Act, assigning the U.S. Forest Service responsibility to keep people out of the area and to control forest fires. As part of the Mt. Hood National Forest, most of the land in the Bull Run Reserve is owned and administered by the Forest Service. The City of Portland owns 3,730 forested acres 
inside this area and another 1,300 acres near the reserve. Visits to the watershed are strictly controlled and monitored.

Long the topic of public debate, Portland's water is treated with the minimum amounts of chlorine and ammonia compatible with public health and safety. The water is tested for purity an average of 500 times a month by Multnomah County's Health Department in a laboratory established at the headworks to assure its continued high quality.

There have been a series of bitter conflicts over the use of the Bull Run watershed in recent years. This is partly due to the fact that only part of the land in the area is actually owned by the City of Portland. Since Congress passed the Bull Run Trespass Act of 1904, the U.S. Forest Service has had responsibility to keep people out of the federally owned part of the watershed and to keep forest fires under control. This generally worked well, until 1958 when private lumber companies offered to safeguard the watershed by means of what was called "protective logging". Although this method does not conform to any known hydrological principles, it was adopted and continued until 1976 when it was challenged by a citizen in U.S. District Court. The court ruled that such practices were both illegal and an ineffective protective mechanism. Renewal of timber contracts was forbidden and access to the watershed was tightened, restricted access to only those individuals actually involved in supplying water to Portland. Also excluded by this decision were Water Bureau employees who were to plan the hydroelectric project.

Congressional action sought by the City of Portland was initiated in 1976. P.I. 95-200, passed in November 1977, resolved the tangle over access to the watershed.

The law established that the principle management objective of the watershed would be the supplying of pure, clear potable water for the Portland Metropolitan Area; no activity would be allowed in the area that could adversely affect the quality of the water in the Reserve and lead to the need for a water filtration plant for P ortland; 
some level of commercial logging will be permitted to continue in the watershed; and the city permitted access to the site to install and operate hydroelectric generators at the reservoirs. In the period after the federal court decision barring all activities not related to water supply and until the signing of P.J.. 95-200, those studying the hydropower potential of the site prepared the entire FERC license application from existing plans or from photographs and inspections of the site obtained by a helicopter, hovering above the ground.

Background of the Project

Hydroelectric generation has been contemplated at the Bull Run site since the construction of Dam No. 1 in the 1920s. Both dams were built with the penstocks required for hydro generation. Periodic studies were conducted assessing the economic feasibility of generating electricity at the dams, but it was the 1975 study by Van Gulick of Oswego, Oregon, which first stated that the project could be viable.

About that time, Portland Utility Commissioner Francis J. Ivancie, who is responsible for public utilities, approached $\mathrm{CH}_{2} \mathrm{M}-\mathrm{Hill}$, a well-established engineering firm, with a number of questions about hydroelectric facility construction, licensing and financing. With the Van Gulick study in hand, Ivancie got the approval from Portland City in the spring of 1976 to develop requests for proposals and award contracts from the city's general funds for engineering support and financial advisory services for the Bull Rụn Hydroelectric Project. An outside advisory and selection panel was convened by the city to evaluate the proposals received. A contract for about $\$ 3$ million in engineering fees was awarded to $\mathrm{CH}_{2} \mathrm{M}$-Hill on the basis of a proposal managed by Bill Waters and Robert Gillette. At about the same time, Smith, Barney, Harris, Upham \& Co., Inc. was awarded a $\$ 60,000$ contract to serve as financial advisor; Frank Schmidt of that firm's San Francisco office has been working with the City on the Bull Run hydroelectric development.

The city's contracts were signed with the engineering and financial advisors in November of 1976. At that time James Doane, currently hydroelectric project manager for the Water Bureau, was first assigned to the project on a part-time basis. Also at 
about that time a Portland-area resident, Joseph Miller, filed suit in U.S. District Court charging that by permitting commercial logging in the area the U.S. Forest Service was violating federal legislation and President Harrison's proclamation restricting access to the Bull Run watershed for the protection of Portland's water supply. In the spring of 1977 Miller won the case and the courts prohibited all access to the watershed for hydropower development, commercial logging and many other activities which were not directly related to city water supply management.

Undaunted, the Bureau of Water Works requested, and was granted, permission by the Court to inspect the site for hydroelectric development from the air while the city of Portland approached the U.S. Congress in search of new legislation concerning the watershed. Using previously drawn plans of the sites in addition to photographs and site inspections from a helicopter which never touched the ground inside the watershed, $\mathrm{CH}_{2} \mathrm{M}$-Hill and the Water Bureau prepared and submitted the FERC license application in October of 1977. Simultaneously, the application was submitted to the State of Oregon for the necessary State licenses and permits.

In November of 1977, the Congress passed P.S. 95-200 which resolved the tangle over access to Federal lands in the watershed. Water supply was established as the principal management objective of the watershed and no activity is to be allowed that could adversely affect the water's quality. The size of the Bull Run watershed Management Unit within the Mt. Hood National Forest was established for this purpose, returning 45,000 acres to regular national forest uses. Some level of commercial logging will be permitted in the watershed, along with hydroelectric development, as long as water quality is not disturbed. Finally, an arbitration board procedure was established in the event of future disputes between the city and the Forest Service.

Also in November of 1977, the city put an issue to the voters on election day which would permit it to enter into long-term power sales contracts -- forty years instead of the previous five-year limit. The issue was passed by the voters and aroused 
no organized opposition.

Oregon has a "central clearinghouse" for the processing of permits. After filing with the State in October of 1977, permits "came around quickly," according to Jim Doane of the Bureau of Water Works. The project was cleared by the State, with the exception of the Oregon department of Fish and Wildlife, by June of 1978. The Oregon Energy Facility Siting Council declared the project for small hydro to fall under their authority.

There were two intervenors in the FERC licensing process: the N.W. Environmental Defense Center operating from the law school at Reed College, and the Oregon Department nf Fish and Wildlife. Both of the interventions were settled without legal battles. The N.W. Environmental Defense Center was concerned about the water quality impact of the Bull Run hydro development. Their objection was withdrawn after the Water Bureau agreed to incorporate special language in the FERC license concerning the preservation of water quality. The Oregon Department of Fish and Wildlife dmanded that the Water Bureau make restitution for the salmon run which was destroyed when Dam No. 1 was constructed without fish ladders in the 1920s. Although the Water Bureau felt the State was making an unreasonable demand, they agreed to place a half million dollars of the revenue generated by the electricity sales, together with payments of $\$ 30,000$ a year over the entire life of the project, toward the State's salmon enhancement program. The Bureau believed that the payments were preferable to the delays, the costs, and the bad publicity they would have had to endure if the case was litigated.

The Water Bureau was not going to pay the reparations without a contest, however. They expect to be assessed $\$ 11,000$ to $\$ 12,000$ per year by the State to appropriate surface waters for hydroelectric generation purposes. They have argued that because the city has been granted the use of the Bull Run waters on federal lands - a right originating in federal legislation, a Presidential proclamation and a U.S. Forest Service 
special use permit -- they are exempt from state water rights regulations, and therefore from the fees the regulations impose. Ultimately this move will be decided by the courts, should no agreement emerge.

In October 1978, the Water Bureau received bids for the construction of the turbines and generators according to the specifications developed by $\mathrm{CH}_{2} \mathrm{M}-\mathrm{Hill}$. In January. of 1979 , a $\$ 4.5$ million contract was awarded to Fujı Electric of Kawasaki, Japan, for the construction of a 24 megawatt Francis unit for Dam NO. 1 and a 12 megawatt Kaplan unit for Dam No. 2. With assistance from the State's congressional delegation, the FERC license was granted on March 28, 1979 -- after an unusually short period of 15 months. This led the way to the finalizing of the power sales agreement the City had been negotiating with the Portland General Electric Co. in April, the City's selling of the tax free industrial development bonds in May, and the beginning of actual construction shortly thereafter.

\section{The Power Purchase Agreement}

The city of Portland does not operate a municipal electric distribution systern. It is served by Portland General Electric Company and Pacific Power and Light Company - both investor-owned utilities. The City and Portland General Electric have entered into an agreement for the purchase of electricity from the Portland Hydroelectric Project at Bull Run.

The energy produced by Bull Run will represent less than one percent of the PGE energy sales. The utility's annual energy requirements are presently generated at hydroelectric facilities (50\%), nuclear power plants (33\%), with the remainder (17\%) supplied by purchased electricity and fossil fuel generating plants..

The average cost of power from the Bull Run Project has been estimated by the City's consulting engineers at approximately 39 mills per kilowatt-hour over the first five years of operation (1983-1987).

On April 12, 1979, Portland General Electric contracted with the city of Portland for the sale and purchase of electric power generated by the hydroelectric power 
generating facilities to be located at Bull Run. The agreement will run until August 30, 2017 , or until the bonds are paid, whichever is later.

All power and energy generated will be delivered to PGE's Bull Run plant about six miles from Dam ${ }^{-N}$ No. 2. PGE will pay all of the annual power costs including debt service on the revenue bonds regardless of the amount of power or energy delivered, if any.

The City and PGE will share future benefits of the Bull Run power "... zs it compares to the cost of energy from the most recently constructed 500 megawatts or greater thermal generating facility on which PGE relies to meet its base load requirement." By fixing the price of Bull Run electricity for PGE at its costs (39mills) plus half the additional cost of new resources, the City has guaranteed itself a steadily growing income from Bull Run. PGE, however, will not be able to experience the dramatic savings typically associated wtih hydroelectric generation, although purchasing from the city may be less expensive than its own capital construction using financing based on a BAA bond rating.

\section{Lessons of the Case Study}

The development of two small hydroelectric power generation facilities in the City of Portland's Bull Run watershed is currently underway and proceeding on schedule.

Those of us participating in this case study found considerably fewer stateimposed regulatory and economic barriere than wc had expccted. The submission of documents used in the application for a FERC license was sufficient to obtain most state licences and permits.

However, in both of the case studies, state and federal processes, legislation and regulations created site-specific, unintended constraints or deadlocks in the developers' schedules. In an attempt to summarize what we have learned about small-scale hydropower and its future, the study team is presenting its observations, conclusions and recommendations below. 
* City water supply dams offer potentially useful small hydroelectric power resources.

Urban areas, particularly those with growing populations and economies, may be able to add to their supply of available electricity by developing resources within easy reach that were previously thought to be economically unfeasible. In many cities, water for domestic consumption has to be brought long distances or held in reserve behind manmade structures. Equipping these structures and delivery systems for the generation of electricity may prove to be an excellent source of revenue for such cities, it may buffer their local economies from what may become drastic electricity shortages in the mid1980s, and it may offset the need to build expensive coal or nuclear thermal generating capacity nearby.

* The work of farsighted planners during system/dam construction are largely responsible for the feasibility of developing small hydropower sites at Bull Run.

When Dam No. 1 was completed in 1929 and Dam No. 2 was completed in 1962 each was cquipped with the penstoeks for the develupment of hydropower. Although the planners of each dam knew the sites were not economically feasible immediately, they had the foresight to envision a day when such developments would be both useful and worthwhile. The costs of constructing hydroelectric facilities at the sites will be considerably less than had the penstocks not been built. The cost savings may have been sufficient to have made the difference in assuring economic feasibility for the sites today, as Portland prepares for predicted future electrical energy shortfalls.

*The State of Oregon's permitting and licensing process posed no serious obstacles to small hydroelectric power development in this case. The central clearinghouse mechanism provided a useful guide through the state's regulations; the costs" of permitting pose no particular threat to the developers. 
The Bureau of Water Works submitted its FERC license application to the Oregon central clearinghouse for development regulations. After that, the state did much of the work in processing the application. Although requirements were placed on the developers due to interventions by the Department of Fish and Wildlife and an environmental group concerned about the quality of Bull Run water, the process itself moved with satisfactory speed, according to Water Bureau officials.

The developers have reached a power purchase agreement with the Portland General Electric Co. (PGE) which will ultimately pay for all costs in the development and licensing process. But the State Legislature should review the fee schedule to determine whether it wishes to charge developers' fees in excess of costs to the state. Such fees are unnecessary at best for small hydroelectric facilities -- at worst they may pose a costly obstacle for marginally economic projects.

* The State Legislature should consider whether they feel it appropriate for the Department of Fish and Wildlife to intervene in licensing proceedings for developments at existing sites, holding such projects hostage until reparations are made for fish or wildlife disturbed during the original site construction.

In the case for Bull Run, the Department of Fish and Game was able to hold up licensing of the hydroelectric project until the Water Bureau promised to make restitution for the salmon runs destroyed during the construction of Dam No. 1 in 1927. Many people might consider this exchange proper because salmon are important to both the ecology and the economy of the region. However, the State Legislature should consider more specific policy guidance to the Department of Fish and Game on small hydroelectric matters. This may include, for example, guidance on the amount they may charge prospective developers, if at all, for salmon runs destroyed many years previous. In some cases, those required to pay restitution may not bethe same individuals or organizations originally responsible for dam construction. The ensuing costs of such interventions both in terms of time lost and in terms of the rising costs of hatchery construction may prove 
prohibitive or counter-productive for some marginal economic sites during this period in which the need to develop future sources of electricity is so important.

* The overlapping of city, state. and federal jurisdictions in the Bull Run watershed area complicated and delayed development plans -- in one case until relief was obtained from Congress. State Legislatures should seek simpler ways to resolve such disputes in the future, such as the arbitration process set up by P.L. 95-100.

As a result of a Presidential proclamation and turn-of-the-century federal legislation, the Water Bureau was not permitted to enter the Bull Run watershed for purpose of hydroelectric development planning, by ruling of a U.S. Circuit Court judge. While awaiting action by the U.S. Congress to allow access for hydroelectric development at the sites, the developers prepared their entire FERC applications using existing plans and photographs taken from a helicopter hovering over the sites. Although the soot and exhausts of the helicopter probably caused more of an environmental impact on Portland's drinking water than a few trips to the watershed by automobile would have had, the activity was technically acceptable within the terms of the law and was the only option short of project delay available to the Water Bureau.

Another question which has arisen as a result of jurisdictional overlaps was brought up by the city: Since the Bull Run watershed is a federal reserve set aside by law, is Portland obligated to pay licensing fees to the State of Oregon? The issue remains unresolved as this report is being completed.

In the next few years, the states and the federal government may need to settle a large number of jurisdictional disputes as the search for future energy resources continues. This is particularly true in western states where the federal government owns so much land. The states should seek a mechanism which does not necessarily require going to Congress or the courts for the resolution of these disputes, such as the arbitration process set up by P.L. 95-100. Such problems appear to be part of what President Carter was referring to recently when speaking of the need to cut through the 
"red tape" unnecessarily delaying the development of important energy projects. However, the states should seek new ways to institutionalize this policy without relinquishing their key interests and the principle of local control over community affairs.

* The States should request that the U.S. Internal Revenue Service review its codes concerning the local furnishing and consumption of electricity.

The administrátively-marked "two county rule" requires that when municipalities sell power to private utilities, the latter must see that all of that power is consumed within two counties, or the revenue bonds financing the project becorne taxable. Although technically it is impossible to "trace" electricity, PGE officials complain that they must take several unusual measures at additional cost to guarantee that all of the Bull Run power must be consumed within two counties. Tax-free bonds save a considerable amount of money to the developers of small hydropower projects and therefore can make a difference in the cost of electricity to the consumer.

The states should ask the IRS to review the "two county rule." Whatever its intrinsic logic, there are many places in the United States where county lines are drawn in a manner which will unintentionally cause the rule to be invoked, adding an unnecessary additional cost to the power from small hydropower developments.

* The City of Portland was able to obtain favorable terms in the power purchase agreement with Portland General Electric because of the utility's unusually weak bargaining position.

Beset with an insufficiency of owned resources, with heavy reliance on the Trojan nuclear power plant to support thier system, with charges of management problems in the development of new resources, BAA capital bond rating and with low public esteem, Portland General Electric is anxious to acquire electrical energy resources at almost any price. As a private utility they presently must take their place in line behind the 
region's many public utilities when vying for inexpensive federal hydropower. (Although this may change if the Northwest Power Bill presently in Congress is enacted.)

PGE's transmission lines run within six miles of the tow dam sites on the Bull Run watershed, so they were the likely power purchasers from the start. But the utility was also anxious to acquire the rights to the power to improve their public relations by demonstrating an interest in environmentally benign sources of electricity (PGE's fondness for nuclear power has been widely publicized, because the city's better bond rating (non-taxable) permitted it to construct the facility more cheaply and, perhaps most important, to cut off lalk of using the Bull Run sites as the beginning of a publicly-owned power system in the City of Portland. Unlike several jurisdictions in the Pacific Northwest and elsewhere around the country, Portland's electric utility companies are privately-owned. Talk of beginning publicly-owned electric power systems -- no matter how serious -- are enough to send a chill through the heart of most private utility executives. The acquisition of power from the Bull Run site seemed to become very important to PGE.

Commisșioner of Public Utilities Francis J. Ivancie led the bargaining for the City of Portland. Ivancie was instrumental in getting City approval for the Bull Run Hydroelectric project; as an elected commissioner he is also firmly grounded in local politics. By aggressively exploiting an unpopular utility's weaknesses, Ivancie seems to have felt he could not only get a good deal for Portland, but he could make political capital in his continuing quest to become its mayor. Well prepared and tough, Ivancie and the Water Bureau succeeded in getting PGE to purchase the electricity from the Bull Run sites, sharing equally the benefits from sites as compared to the cost of energy from the most recently constructed 500 megawatts or greater thermal base load generating facility which PGE uses.

This hard bargain for the relatively small amount of available power caused some resentment at PGE where the study team was told that "it will be a long day" before 
PGE agrees to "share-the-benefits" agreement again. Although such blustering may come to naught, it is clear that the Water Bureau is marketing its power, not entering into a "partnership" in development with the utility (such as the one into which Seattle City Light and Tacoma City Light have entered with the South Columbia Basin Irrigation District for the development of small hydropower sites). Only time will tell whether this strategy of independence will be more useful or more harmful for the developers of small hydroelectric power facilities.

*Careful attention will be paid to the environmental effects of hydroelectric generation at these sites. Aside from this particular environmental concern, the Bull Run Hydrnelertitic Project has enjoyed support from city and state institutions and the press. This may be the basis for cautious optimism for the future of similar projects.

Because of Portland's concern for the quality of its drinking water, strict tests will be performed to evaluate the impact of hydropower development on delivered water quality. The certainty of this testing was further guaranteed when the Water Bureau accepted special wording in its FERC license concerning water quality in order to satisfy an intervenor. The findings of these studies will be of considerable interest to those other cities contemplating similar developments.

The Water Bureau had to openly solicit voter approval of the project when an issue was placed on the hallnt to permit the city to raise from five to forty years the maximum length of its sales agreements. The issue, which carried, was necessary before a power sales agreement could be reached. This example vividly demonstrates the belief of the study team that unintended, site-specific obstacles to small hydroelectric generation will emerge everywhere such projects are planned. Only through the cooperation of all the parties at interest will these obstacles be eliminated. 
APPENDIX A

ESTIMATED CAPITAL COSTS

FOR P.E.C. 22.7

Item

Land and Land Rights

Structures and Improvements

Reservoirs, Dams and Waterways

Water Wheels, Turbines and Generators

Accessory Electric Equipment

Misc. Power Plant Equipment

Roads, Railroads and Bridges

Subtotal at March 1978 Prices

Contingencies

Escalation to May 1980 Prices

State Sales Tax

Engineering, Construction Management, District

Expense, Financing and Legal Fees

Funded Interest Less Investment Income

Total Project Investment
Cost

$\$ \quad-0-$

340,000

396,000

$1,037,000$

203,000

45,000

21,000

$\$ 2,042,000$

$\$ 306,000$

427,000

141,000

641,000

166,000

$\$ 3,725,000$

(courtesy SCBID and Tudor Engineering Co.) 


\begin{tabular}{|c|c|c|c|c|c|c|c|c|c|c|c|c|c|}
\hline & & YEAR & & & & & & 198 & & & & 1981 & \\
\hline & & ITEM & & & RATE & $\mathrm{u}$ & A & $5 \mid 0$ & $N$ & D & $J|F|$ & M A & in \\
\hline & 0. & $11 \mathrm{EM}$ & UNII & Qir. & MONTH & 1 & 2 & $3 \mid \begin{array}{lll}3 & 4\end{array}$ & 5 & 6 & $7 \mid 8$ & $9 \mid 10$ & 11112 \\
\hline$\geqq$ & (5) & MOBU17E & 15 & & & & & & & & & & \\
\hline & & & L.S. & 1 & & E & & & & & & & \\
\hline & & & & & & & & & & & & & \\
\hline$\frac{\partial}{\Sigma}$ & 2 & ACCESS ROAC & L.F. & 7000 & 5000 & & 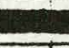 & & & & & & \\
\hline & & & & & & & & & & & & & \\
\hline ن & 2 & PARKING LOT & S.F. & 4000 & 10,000 & & & & & & & - & \\
\hline $\bar{\Sigma}$ & 4 & POWERLINE & L.F. & 1000 & 2000 & & & & & & & 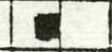 & \\
\hline & & & & & & & & & & & & & \\
\hline & & PENSTOCK \& INLET STRUCTURE & & & & & & & & & & & \\
\hline בِ & 5 & EXCAVATE & C.Y. & 5300 & 3000 & & & & $=$ & & & & \\
\hline 足 & 6 & DEMOLITION & L.S. & 1 & & & & & 1 & & & & \\
\hline & 7 & CONCRETE & C.Y. & 450 & 500 & & & & 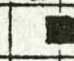 & 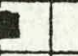 & & & \\
\hline & 8 & INSTALL PENSTOCK STRUCTURAL & L.S. & 1 & & & & & & E & & & \\
\hline & & STEEL & & & & & & & & & & & \\
\hline & & & & & & & & & & & & & \\
\hline & & POWERHOUSE \& TAILRACE & 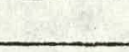 & & & & & & & & & & \\
\hline & 9 & EXCAVATION & C.Y. & 4500 & 3000 & & & & $=$ & & & & \\
\hline & 101 & DEMOLITION & L.S. & 1 & & & & & a & & & & \\
\hline & 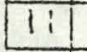 & FOUNDATION CONCRETE & C.Y. & 300 & 1000 & & & & & 2 & & & \\
\hline & 12 & SUPERSTRLCTURE CONCRETE & C. Y. & 1000 & 500 & & & & & & & & \\
\hline 25 & 13) & INSTALL TURBINE \& GENERATOR & L.S. & 1 & & & & & & & & - & \\
\hline $\bar{E}$ & i4] & INSTALL ELECTRICAL / & L.S. & 1 & & & & & & & & $=$ & \\
\hline 嵌。 & I & MECHANICAL EQUIPMENT & & & & & & & & & & & \\
\hline Q랑 & $15 !$ & TEST AND START UP & L.S. & 1 & & & & & & & & & \\
\hline & & & & & & & & & & & & & \\
\hline & 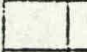 & SWITCHYARD & & & & & & & & & & & \\
\hline$\frac{\pi}{5}$ & 18 & EXCAVATE & C.Y. & 7000 & 3000 & & & & & & & & \\
\hline 至 & 17 & CONCRETE & C.Y. & 50 & 100 & & & & & & & E & \\
\hline$\stackrel{\varrho}{\underline{E}}$ & 18 & INSTALL TRANSFORMER \& & L.S. & 1 & & & & & & & & 10 & \\
\hline$\sum_{\omega}^{1}$ & 1 & E!ECTRICAL EQUIPMENT & & & & & & & & & & & \\
\hline & 1 & & & & & & & & & & & & \\
\hline 35: & 191 & CLEAN UP AND MOVE OUT & L.S. & 1 & & & & & & & & & $=$ \\
\hline & & - & & & & & & & & & & & 11 \\
\hline & & WATER IN CANAL & & & & & & & & & & & 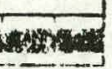 \\
\hline
\end{tabular}


APPENDIX B

ESTIMATED CAPITAL COSTS

FOR BULL RUN SITES

Powerhouse No. 1 Powerhouse No. 2 (24-MW) - $(12-\mathrm{MW})$

Hydraulic Production

Land and Land Rights

$$
\begin{array}{r}
-0- \\
1,327,400 \\
449,800 \\
\\
3,797,000 \\
365,000 \\
\\
482,000 \\
635,800
\end{array}
$$

Reservolrs, Dams, and Waterways

Waterwheels, Turbines, and

Generators

Accessory Electrical Equipment

Miscellaneous Power Plant

Equipment

Roads, Rallroads, and Bridges

$$
\begin{array}{r}
\$ \quad-0- \\
1,091,100 \\
229,900 \\
4,090,000 \\
300,000 \\
\\
448,000 \\
120,000
\end{array}
$$

$$
-0-
$$

17,000

268,000

342,000

157,000

$$
\begin{array}{r}
-0- \\
17,000 \\
172,000 \\
76,000 \\
43,000
\end{array}
$$

Overhead Conductors and Devices

General Plant

Communication Equipment

65,000

26,000

Construction Cost

$\$ 7,906,000$

Construction Cost (1977 Dollars)

(Powerhouse Nos. 1 and 2, plus

Transmission Line)

$\$ 14,519,000$

Total Indirect Costs (i.e., Inflation, Engineering, CMS, Administrative, Legal, Financing, Interest During Construction, and Contingencies)

$13,641,000$

Totàl Project Cost Estimate

$\$ 28,160,000$ 
ESTIMATED CAPITAL COSTS

FOR BULL RUN SITES

Hydraulic Production

Lend and Land Rights

Structures and Improvements

Reservoirs, Dams, and Waterways

Waterwheels, Tuxbines, and

Generatinrs

Accessory Electrical Equipment

Miscellaneous Power Plant

Equipment

Road̉s, Railroads, and Bridges

Transmission Plant

Land and Land Rights

Structures and Improvements

Station Equipment

Poles and Fixtures

Overhead Conductors and Devices
Powerhouse No. 1 (24-MW) inwerhouse Nis. 2 (12-MW)

General Plant

Communication Equipment

65,000

$\$ \quad-0-$
$1,091,100$
229,900

$1,327,400$

449,800

$3,797,000$

365,000

$4,090,000$

300,000

482,000

$6.35,8 \cap 0$

448,000

130,000

$-0-$

17,000

172,000

76,000

43,000

Congtruction cost

$$
\overline{\$ 7,906,000} \quad \overline{\$ 6,613,000}
$$

Construction Cost (1977 Dollars)

(Powerhouse Nos. 1 and 2, plus

Transmission Line)

$\$ 14,519,000$

Total Indirect Costs (i.e.; Inflation, Engineering, CMS, Administrative, Legal, Financing, Interest During Construction, and Cortingencies)

Total Project Cost Estimate

$13,541,000$

$\$ 28,160,000$ 
UNITED STATES

DEPARTMENT OF ENERGY

WASHINGTON, D.C. 20585

OFFICIAL BUSINESS

PENALTY FOR PRIVATE USE. $\$ 300$
POSTAGE AND FEES PAID

U.S. DEPARTMENT OF ENERGY DOE 360

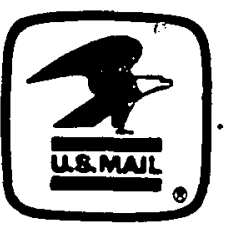

